\title{
Ranchers, Farmers, Soldiers, and the CCC: The Background for Seven Historical Sites at Camp Bowie, Brown County, Texas
}

John J. Leffler

Follow this and additional works at: https://scholarworks.sfasu.edu/ita

Part of the American Material Culture Commons, Archaeological Anthropology Commons, Environmental Studies Commons, Other American Studies Commons, Other Arts and Humanities Commons, Other History of Art, Architecture, and Archaeology Commons, and the United States History Commons

Tell us how this article helped you.

This Article is brought to you for free and open access by the Center for Regional Heritage Research at SFA ScholarWorks. It has been accepted for inclusion in Index of Texas Archaeology: Open Access Gray Literature from the Lone Star State by an authorized editor of SFA ScholarWorks. For more information, please contact cdsscholarworks@sfasu.edu. 
Ranchers, Farmers, Soldiers, and the CCC: The Background for Seven Historical Sites at Camp Bowie, Brown County, Texas

\section{Creative Commons License}

\section{(c) (1) (8)}

This work is licensed under a Creative Commons Attribution-NonCommercial 4.0 International License 


\section{Ranchers, Farmers, Soldiers, and the CCC: The Background for Seven Historical Sites at Camp Bowie, Brown County, Texas}

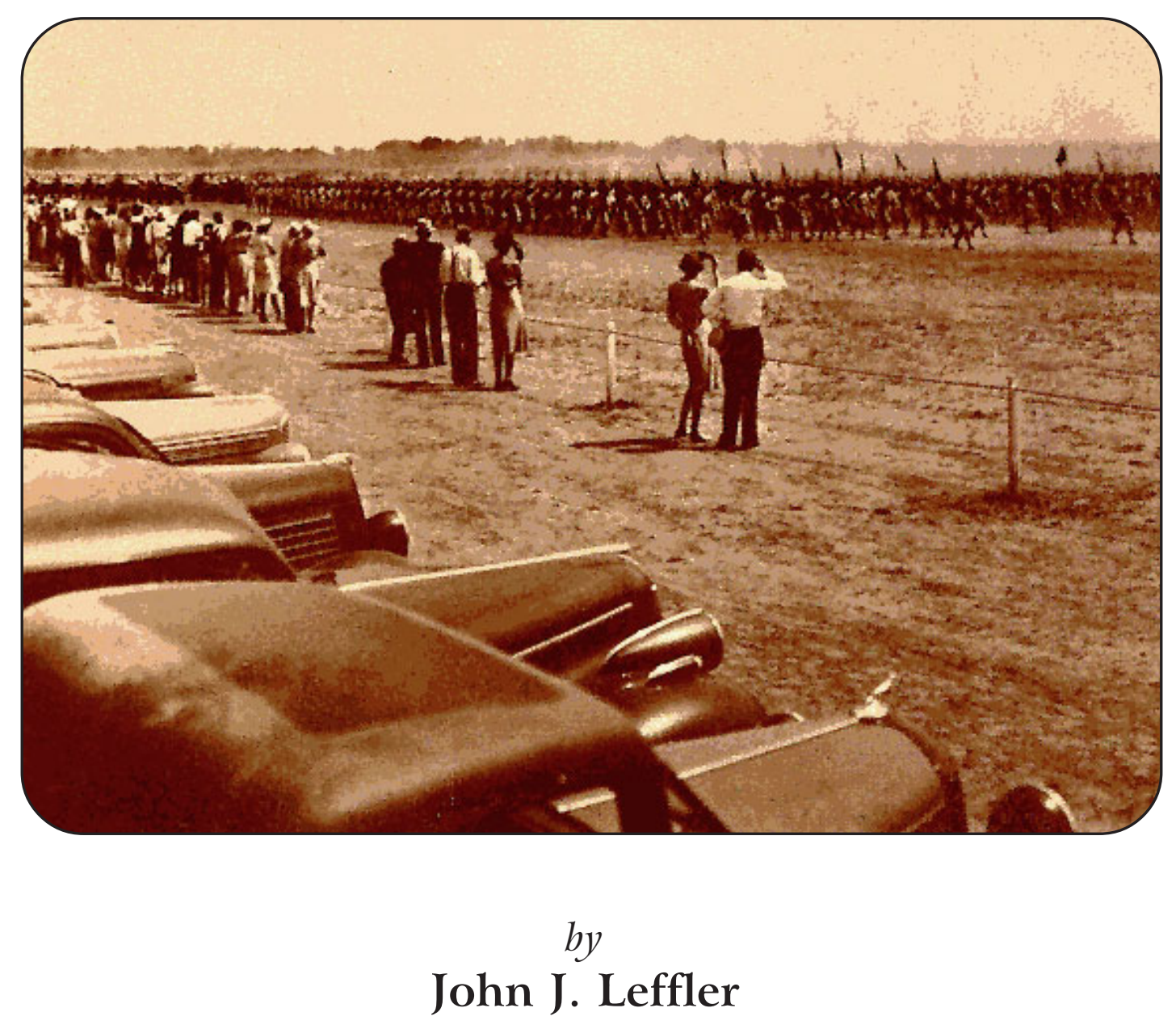

The Adjutant General's Department of Texas Directorate of Facilities and Engineering Environmental Branch, Austin, Texas
Center for Archaeological Research The University of Texas at San Antonio Archaeological Survey Report, No. 325

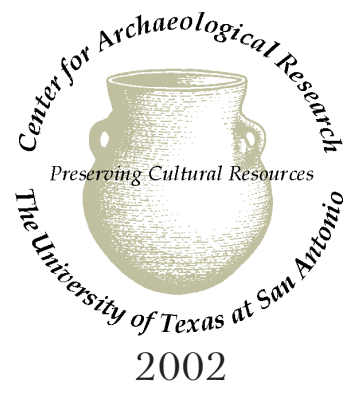




\title{
Ranchers, Farmers, Soldiers, and the CCC: The Background for Seven Historical Sites at Camp Bowie, Brown County, Texas
}

\author{
by \\ John J. Leffler
}

Raymond P. Mauldin

Principal Investigator

Texas Antiquities Permit No. 2591

Prepared for:

Adjutant General's Department of Texas Directorate of Facilities and Engineering Environmental Branch, Austin, Texas http://www.agtx-ev.pollution.org
Prepared by:

Center for Archaeological Research The University of Texas at San Antonio Archaeological Survey Report, No. 325 http://car.utsa.edu

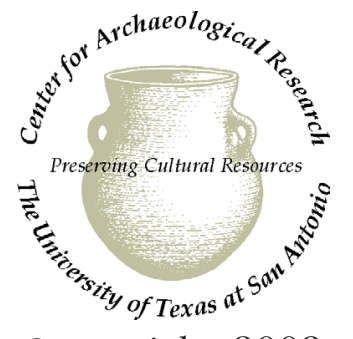

(C)copyright 2002 
The following information is provided in accordance with the General Rules of Practice and Procedure, Chapter 41.11 (Investigative Reports), Texas Antiquities Committee:

1. Type of investigation: Archival

2. Project name: Archival study of seven historical sites at Camp Bowie

3. County: Brown

4. Principal investigator: Raymond P. Mauldin

5. Name and location of sponsoring agency: Adjutant General's Department of Texas, Environmental Division, AGTX-EV P.O. Box 5218, Austin, Texas, 78763-5218

6. Texas Antiquities Permit No.: 2591

7. Published by the Center for Archaeological Research, The University of Texas at San Antonio, 6900 N. Loop 1604 W., San Antonio, Texas 78249-0658, 2002

A list of publications offered by the Center for Archaeological Research is available. Call (210) 458-4378; write to the Center for Archaeological Research, The University of Texas at San Antonio, 6900 N. Loop 1604 W., San Antonio, Texas 78249-0658; e-mail to car@lonestar.utsa.edu; or visit CAR’s web site at http://car.utsa.edu. 


\begin{abstract}
During the mid-1990s, a cultural resources survey of Camp Bowie was conducted by the Environmental Resources Management Branch of the Adjutant General's Department of Texas (AGTX-EV) which identified a number of historical sites within the camp's boundaries. These sites included 41BR227, 41BR438, and 41BR266, all of which are sandstone walls; 41BR270 and 41BR477, both of which contain check dams built to control erosion; 41BR290, the remains of a farmstead; and 41BR299, a bunker dating to the World War II era. In 2001 the Center for Archeological Research at The University of Texas at San Antonio contracted with AGTX-EV to conduct additional archaeological investigations at Camp Bowie; part of that agreement called for a general investigation of the historical background of the seven sites mentioned above. This archival research was conducted under Texas Antiquities Permit no. 2591.
\end{abstract}




\section{Contents}

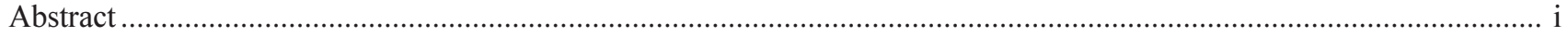

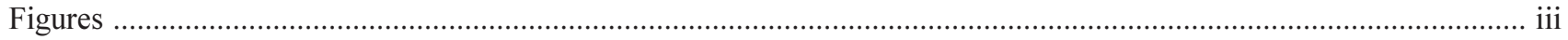

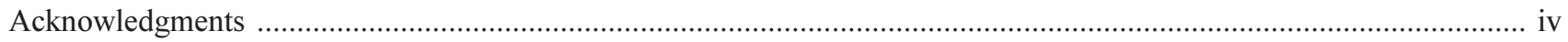

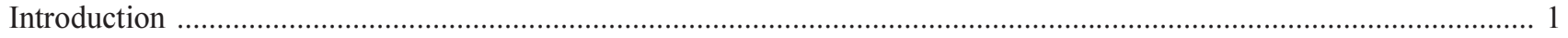

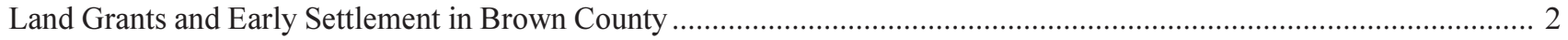

The Development of Brown County and the Camp Bowie Area, 1861-1900 ……................................................... 9

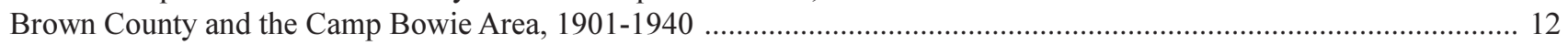

Check Dams and the Civilian Conservation Corps in Camp Bowie ...................................................................... 14

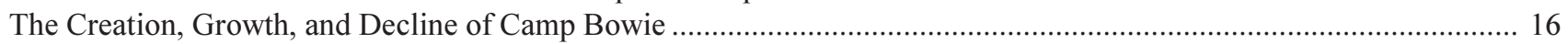

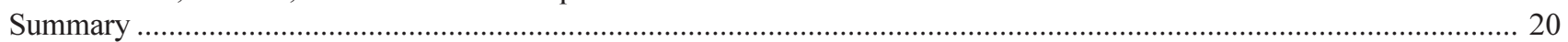

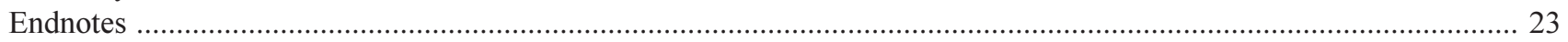

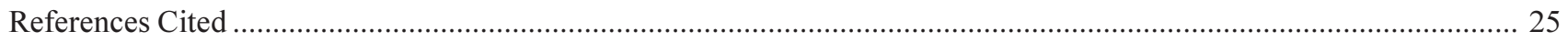

Appendix A

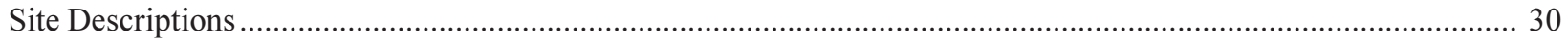

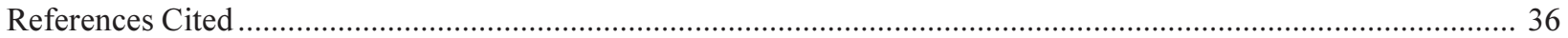




\section{Figures}

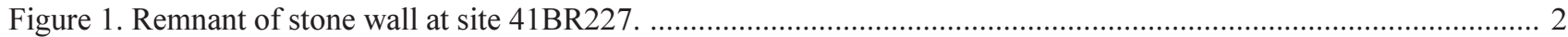

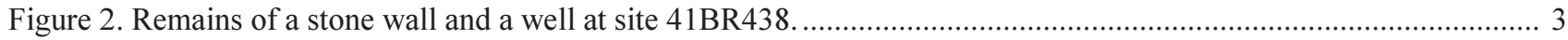

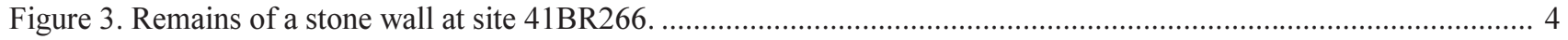

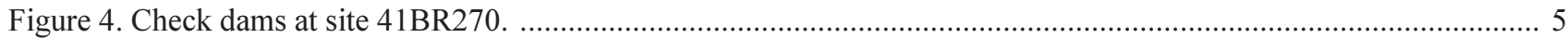

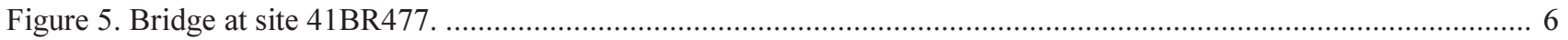

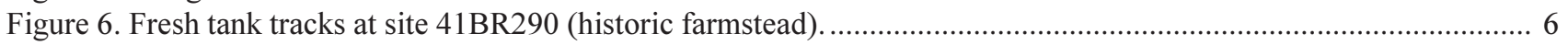

Figure 7. The bunker at site 41BR299, southern elevation. ............................................................................... 7

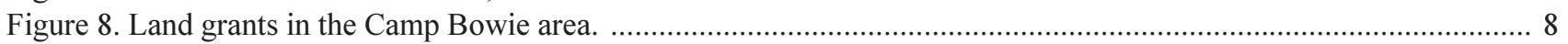

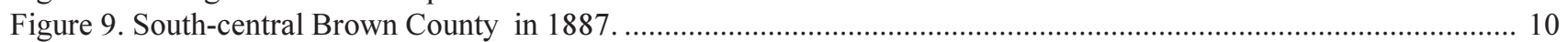

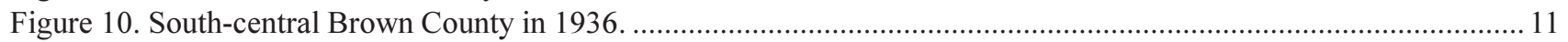

Figure 11. Map showing the location of the CCC camp at Camp Bowie, 1941-1942 ................................................ 15

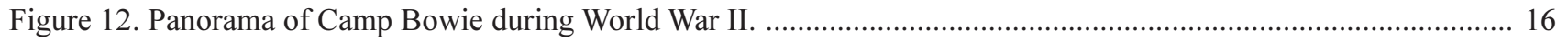

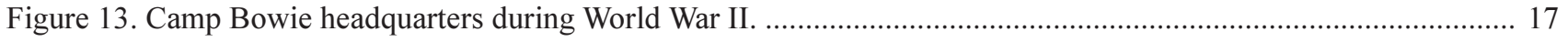

Figure 14. A post exchange at Camp Bowie during World War II. ........................................................................ 17

Figure 15. Troops at Camp Bowie march in review, May 1941 ....................................................................... 18

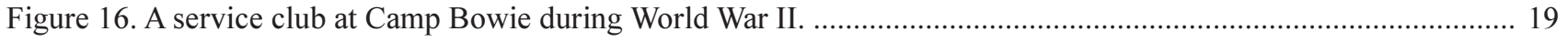

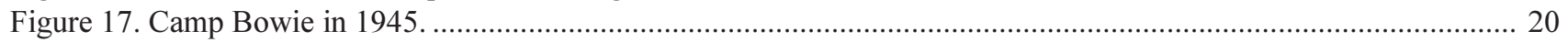

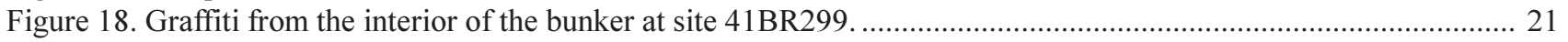

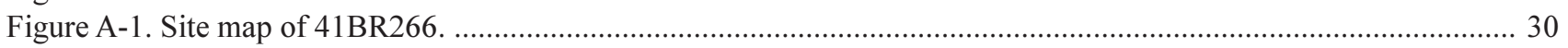

Figure A-2. Site map of 41BR270 - overview of the site. .............................................................................. 31

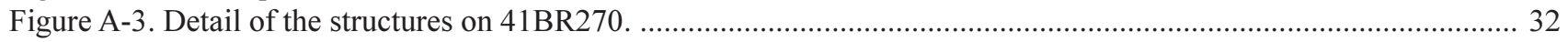

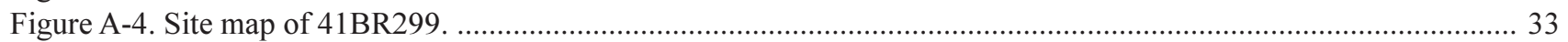

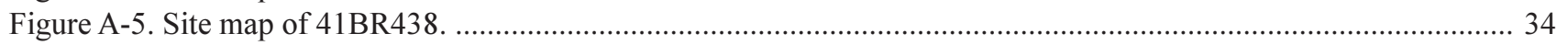

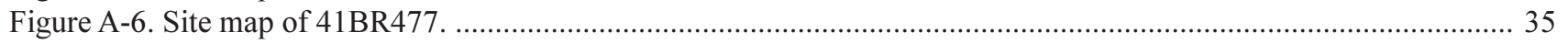




\section{Acknowledgments}

Dozens of people contributed to the completion of this study. I would like to thank, first, Shellie Sullo-Prewitt, Gene Davis, Alan Wormser, Stephen Stringer, Christina Leshley-Prikryl, and Michael Jordan, whose previous research unearthed or produced a number of documents, maps, publications, photos, site descriptions, and other sources that proved very useful. Shellie Sullo-Prewitt was particularly responsible for making these materials available to me, and her gracious help throughout the project is greatly appreciated. Thanks also to Lorene Bishop, Ronnie Lappe, and Cullen Perry, who generously shared their knowledge of Brown County with me and pointed me toward various sources. The always-helpful Jim Steely gave me some of his own research materials regarding the Civilian Conservation Corps and helped me focus my research on that topic. The project could not have been completed without the assistance of the professional, knowledgable staff members at the Center for American History at The University of Texas Austin; the Texas General Land Office; the Texas State Library and Archives; the Brown County Clerk's Office; the Brown County Tax Appraisal Office; the Brownwood Public Library; and the Brownwood Chamber of Commerce. Several people at the Center for Archaeological Research (CAR) contributed materially to the study. Many thanks to Steve Tomka, CAR's director, for his logistical help and for his patience and good humor; to Bruce Moses, who produced the maps; to Raymond Mauldin, who went out of his way to get me photos of the sites; and to Johanna Hunziker and Maryanne King, who edited the piece for publication. And special thanks to Sherri Suñaz, administrative assistant at CAR. 


\section{Introduction}

Camp Bowie was created as a training facility for the Texas National Guard's 36th Infantry Division in September 1940, as the United States began to beef up its defense forces after Germany invaded Poland, France, and the Low Countries. Named for Alamo legend James Bowie, it was the first major defense facility built in Texas during the World War II era, and it eventually became the largest. By February 1941 more than 8,000 buildings had been constructed on the camp, and after the United States entered the war in December 1941, Camp Bowie continued to expand.

Over the course of World War II many U.S. infantry and artillery units trained or were stationed at Camp Bowie, including the 36th Division, units of the Iowa National Guard, and elements of the Eighth Service Command and of the Third, Fourth, and Eighth Army Corps. In all, over 200,000 men trained at Bowie during the war. Between 1941 and 1943, Bowie also contained a Civilian Conservation Corps camp and in 1943 a prisoner-of-war facility capable of holding 3,000 men was established. By 1945 Camp Bowie's original 2,000-acre campsite had grown to a 5,000acre cantonment district, and with its 118,000-acre maneuver area the camp sprawled across 123,000 acres in Brown and Mills counties.

In 1940, before the camp was created, most of south-central Brown County was occupied by ranches and stockfarms. Agriculture had dominated the local economy since the $1850 \mathrm{~s}$, when the area was first settled. In the 1860 s and 1870 s its grasslands attracted cattlemen; during and after the 1880s the arrival of railroads encouraged thousands of farmers to move into Brown County. The area did not contain prime farmland; most of its hilly, rocky surface was never good for much except grazing. It did, however, contain many pockets of flat land with soil good enough to grow cotton, corn, and other crops. In the late nineteenth and early twentieth centuries more and more people moved into southcentral Brown County, and a few small communities, such as Indian Creek, Dulin, Elkins, and Woodland Heights, began to grow.

The area encompassed by present-day Camp Bowie seems to have developed along the lines of the rest of south-central Brown County, but even more slowly and incompletely. Ranching and stockfarming defined the local economy. There is no evidence that any communities were ever established there (though some existed nearby), and by the mid-1930s only one significant road cut into the area. At that time the land that is now Camp Bowie, like the rest of south-central Brown County, was sparsely populated, and its ranchers and stockfarmers were just barely getting by.

During the 1920s and especially during the Depression years of the 1930s, Brown County's ranchers, farmers, and communities had been hammered by low prices and low production. During the 1930s the federal government offered help through the Agricultural Adjustment Administration, farm loan guarantees, and other New Deal programs. Two Civilian Conservation Corps camps were established in the area; one of these worked constructing facilities for what is now the Lake Brownwood State Recreation Area; the other worked with county landowners on soil conservation projects. Nevertheless, many farmers and ranchers in Brown County continued to struggle, and a number lost their lands. In 1940, with the area still mired in the Depression, local officials and boosters began to organize an effort to attract an Army camp to the area, hoping to stimulate the county's economy.

Though the original Camp Bowie was deliberately placed in south-central Brown County partly because the area was lightly populated (even by Brown County standards) the camp's creation and, especially, its subsequent expansion led to the displacement of over a hundred families and the disintegration of three small communities. Probably because Camp Bowie was the earliest World War II-era training center in Texas, the federal government at first acquired land for Bowie through a different process than it used at similar Texas military facilities -Camp Maxey and Camp Swift for example- which were established after the U.S. had actually entered the war. At Maxey and Swift the government was able to simply and quickly condemn the properties it needed by invoking the exigencies of war. At Camp Bowie, however, the government at first leased the land it wanted, apparently from willing landowners. Only in September 1942 -when the camp's size was doubled to expand its maneuver areasdid the government resort to land condemnations.

In November 1946, after the war was over, the original Camp Bowie was decommissioned, and the last troops left in January 1947. Most of the camp's land was sold to the public (in some cases to the former owners of the properties), but 


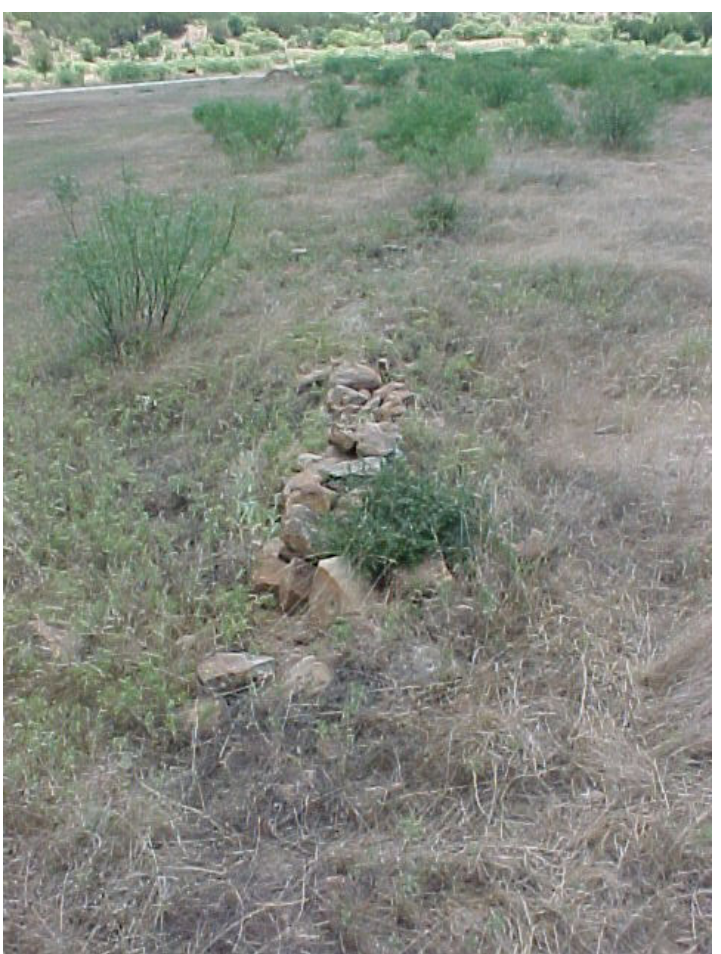

Figure 1. Remnant of stone wall at site 41BR227.

the federal government retained control of several thousand acres. In April 1949, 5,411 acres of the original Camp Bowie were deeded to the Texas National Guard, which subsequently established its own training facility there.

During the mid-1990s, a study of Camp Bowie conducted by Shellie Sullo-Prewitt, Gene Davis, Alan Wormser, and Stephen Stringer of the Environmental Resources Management Branch of the Adjutant General's Department of Texas (AGTX-EV) identified a number of historical sites within the camp's boundaries (Wormser and Sullo-Prewitt 2001). These included sites 41BR227, 41BR438, and 41BR266, all of which are sandstone walls; sites 41BR270 and 41BR477, both of which contain check dams built to control erosion; site 41BR290, the remains of a farmstead; and site 41BR299, a bunker dating to the World War II era (Figures 1-7). The following discussion provides a general historical background for these sites and some of the people and events associated with them. Site descriptions from the original survey report (Wormser and Sullo-Prewitt 2001) are included in Appendix A of this report.

\section{Land Grants and Early Settlement in Brown County}

In the early nineteenth century, the area that is now known as Brown County was a "vast pastureland" of luxuriant grasses punctuated by patches of mesquite, post oak, and pecan trees. Buffalo, deer, antelope, bears, and panthers roamed the region, which at that time was controlled by Penateka Comanches. Though a Spanish expedition commanded by Captain Nicolas Flores de Valdez had passed through briefly in 1723, the Comanches maintained their control of the area for twenty years after the Texas Revolution. ${ }^{1}$

English-speaking Texans began to become familiar with the region during the 1820s. In 1828 a group of twenty-eight men led by Captain Henry Stephenson Brown crossed Pecan Bayou in pursuit of a Comanche raiding party; they attacked two Indian encampments and engaged in a pitched battle on Home Creek before returning to Gonzales. Ten years later another group of men led by Lieutenant Andrew Van Thuysen journeyed through the area; and that same year three men conducted the first land survey there. No additional surveys were made, however, until 1846 and 1847 , when a surveying party from the Bexar County Land District laid out eighty-six tracts in what would later become Brown County. ${ }^{2}$ Although no settlers had moved into the area yet, the surveyors were locating land grants that had been awarded by the Republic of Texas and the State of Texas during the 1830s and 1840s. Among these were the Bernard E. Bee survey (later associated with historical site 41BR227), the Reuben Ross survey (associated with 41BR270), the James Cotton survey (associated with 41BR438), and the Henry Tolley survey (associated with 41BR227; Figure 8).

The Bee tract, laid out in May 1846, located a 1,280-acre bounty grant awarded by the State of Texas to Bernard E. Bee for his military service just after the Texas Revolution. Bernard Elliot Bee, Sr., was one of the most prominent men in early Texas history. Originally from South Carolina, where he studied law, Bee moved his family to Texas during the summer of 1836 and settled near Houston. Bee was one of the Texans who escorted General Antonio Lopez de Santa Anna to Washington after the Battle of San Jacinto. He served in the Army of the Republic of Texas, then resigned to become, first, the new Republic's Secretary of the Treasury and then its Secretary of State. During the late 1830 s and early 1840s he served the Republic as one of its chief diplomats, and engaged in high-level treaty 

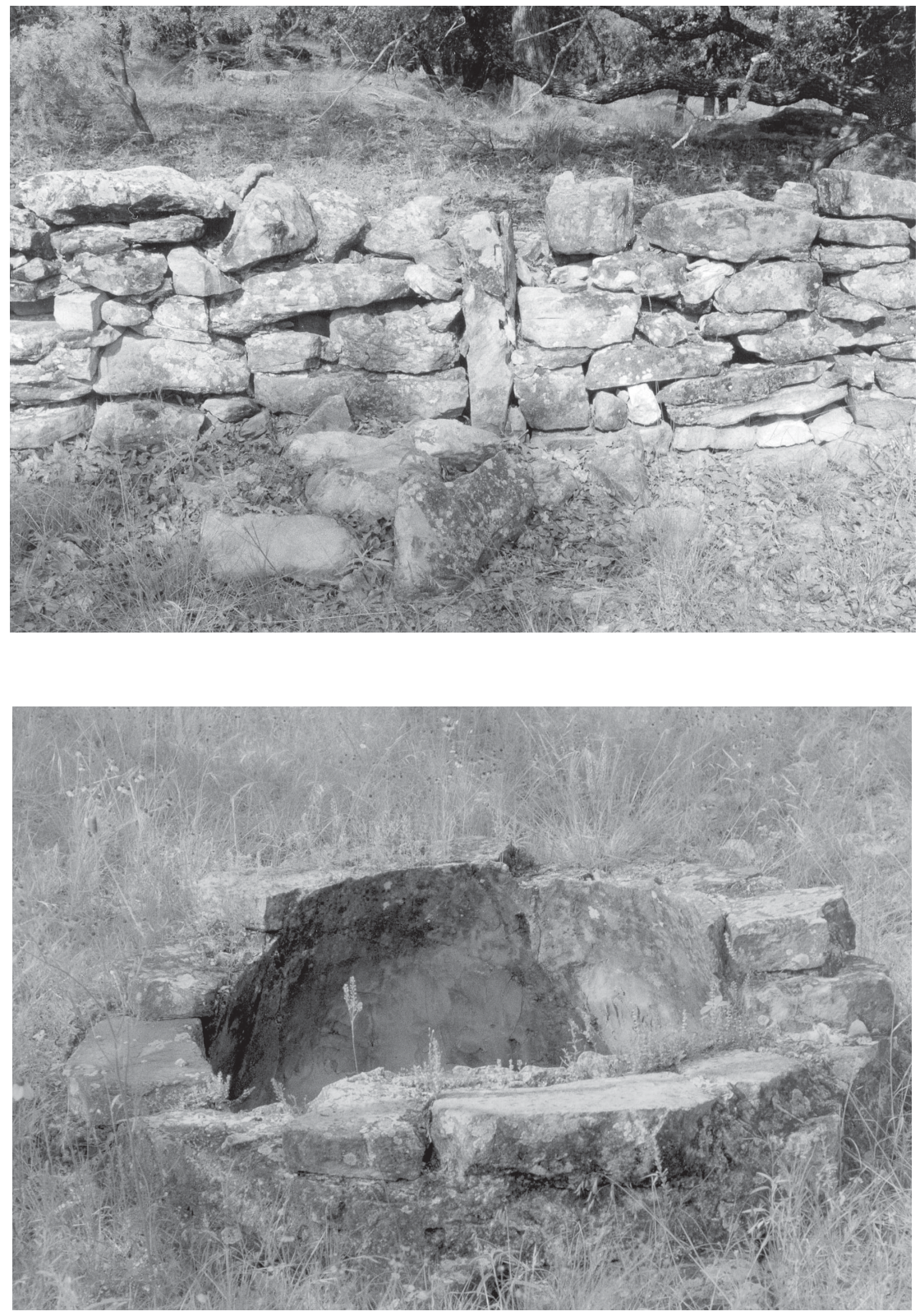

Figure 2. Remains of a stone wall (top) and a well (bottom) at site 41BR438. Photos by Alan Wormser, 1995. 


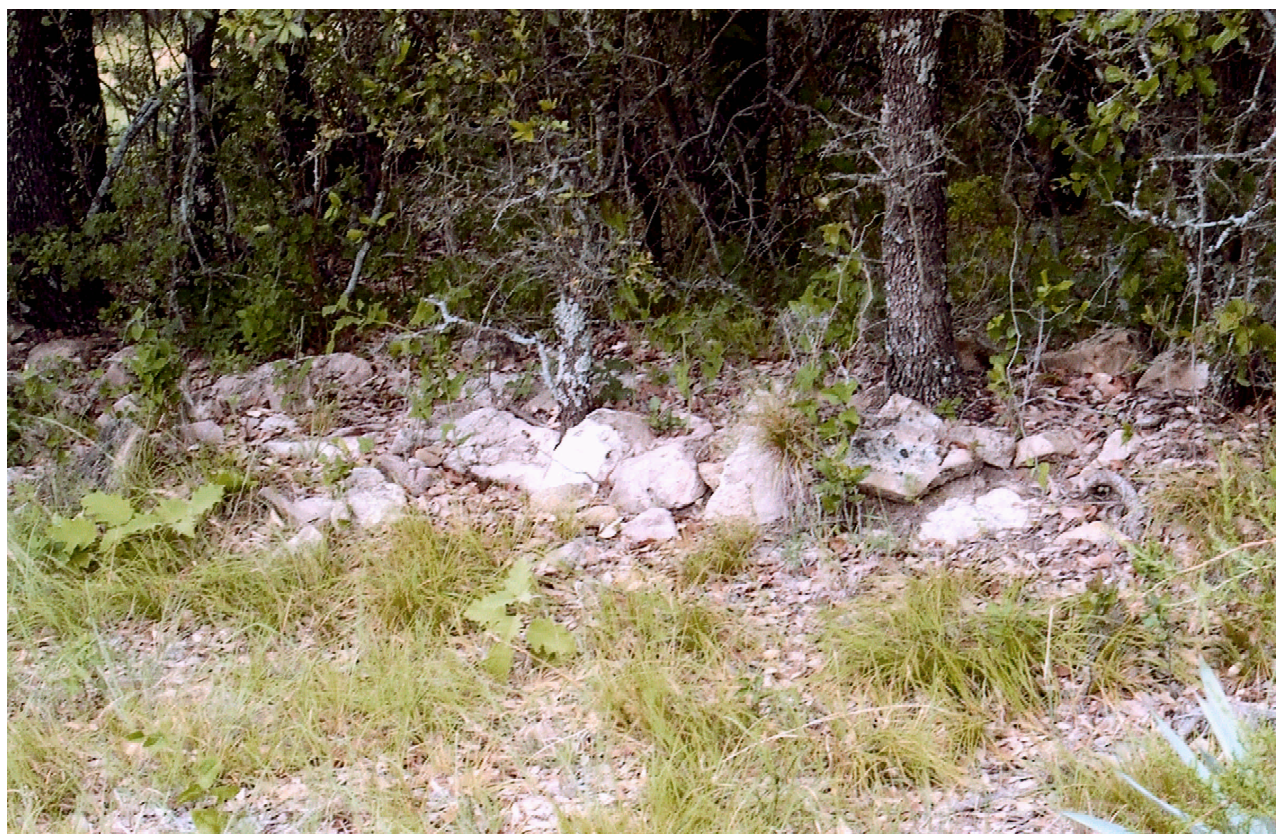

Figure 3. Remains of a stone wall at site 41BR266. Photo by John Leffler, 2001.

negotiations with the governments of Spain, Mexico, and the United States. By February 1846, when Bee was awarded his land grant, his diplomatic career had ended. There is no reason to believe that he ever intended to live on, or even visited, the Camp Bowie property. It is likely he intended to sell it or held it for speculative purposes. Shortly after establishing his claim to the land, Bee moved back to South Carolina, and was still living there when he patented his deed to the property in July 1847 . He died in South Carolina in $1854 .^{3}$

The Ross tract, also surveyed in May 1846, located a 1,280acre bounty grant that had been awarded by the Republic of Texas in 1838 to Reuben Ross for his military service during the Texas Revolution. Ross was originally from Virginia but was living in Texas by 1836, when he enlisted in a volunteer cavalry company to fight against Santa Anna. By December 1837, when he was discharged from the Army of the Republic of Texas, Ross had risen to the rank of captain. $\mathrm{He}$ was serving as the captain of the Houston Volunteer Guards in August 1838 when he received his bounty grant, which entitled him to locate, survey, and hold 1,280 acres. It is virtually certain that Ross never visited the property later surveyed under his grant: on August 16, 1838, only five days after receiving the grant certificate, he sold it to one Thomas H. Harris for \$200. Ross died in a duel the next year. ${ }^{4}$
Harris was clearly a speculator: in March 1839, less than eight months after he had purchased Ross' certificate, he sold it for $\$ 300$ to one William H. Beasley. Unlike Harris, Beasley held onto the certificate for several years. In 1846 he used it to survey and claim what became known as the Ross survey, which was patented to Beasley in 1851. It is not known whether Beasley ever lived on the property (the first settlers did not arrive in the area until 1856), but if he did he didn't stay long; according to the U.S. census, there were no Beasleys living in Brown County in 1860. ${ }^{5}$

The James Cotton survey (associated with site 41BR438) located a third-class grant awarded to Cotton by the Harris County Board of Land Commissioners in June 1845. Little is known about Cotton except that he lived in Houston when he received his headright, which he had already sold to C. A. Hopson and John I. Cain. Little is known about Hopson, but Cain may have been related to the John Cain who died at the battle of the Alamo. Cain and Hopson patented the property in July 1847 , but they were probably speculators; Cain located at least one other land grant in the area during this period, and neither Cain nor Hopson appear on the 1860 U.S. census for Brown County. ${ }^{6}$

The Henry Tolley tract (associated with 41BR227), surveyed in February 1846, was an 1839 second-class grant to Tolley; because he and his family had arrived in Texas in May, 1836, 

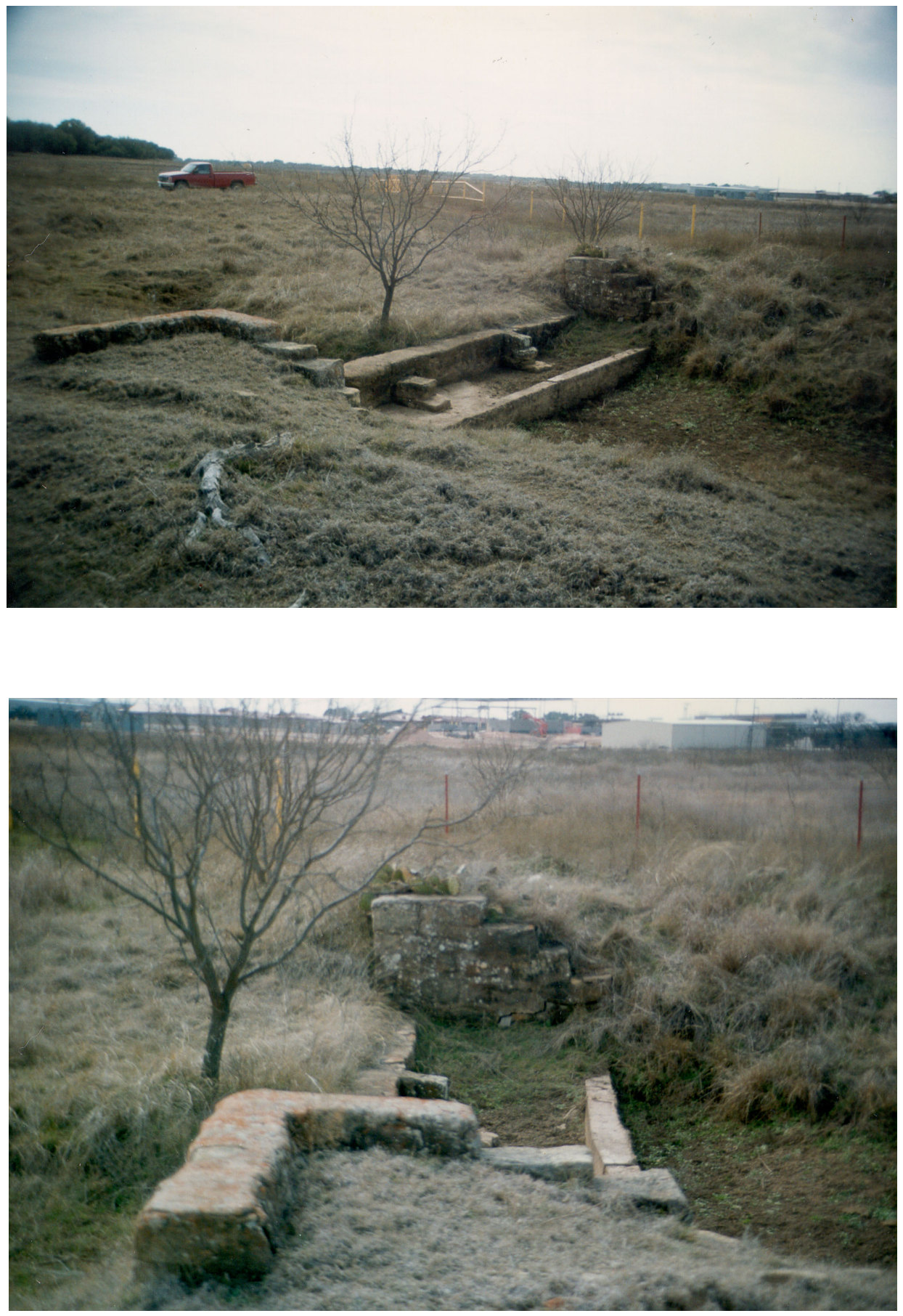

Figure 4. Check dams at site 41BR270. Photos by Alan Wormser, 1994. 


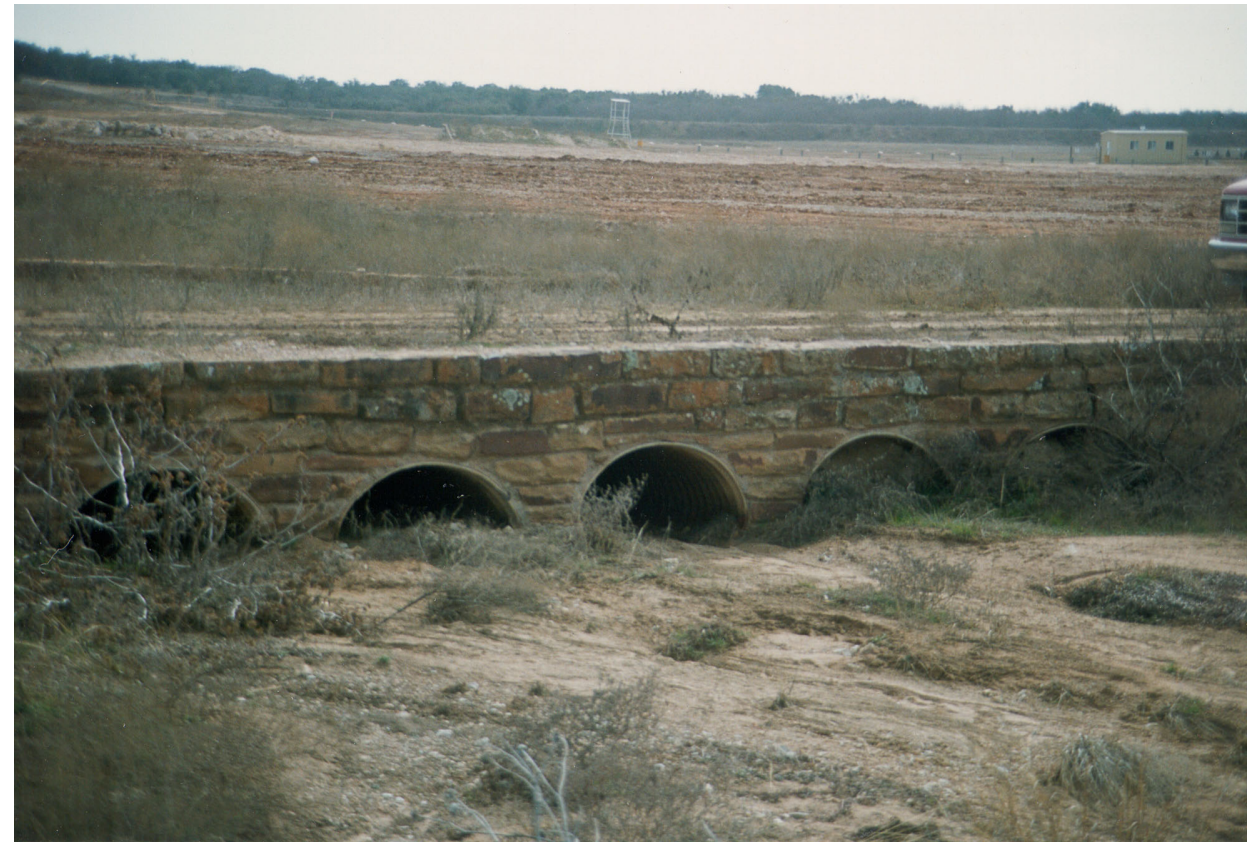

Figure 5. Bridge at site 41BR477. Photo by Alan Wormser, 1994.

he qualified under the laws of the Republic to receive 1,280 acres. Little information can be gathered pertaining to Tolley; but like the others who located land grants in the Camp Bowie area during the 1840 s, it is not likely that he or any members of his family moved to their lands there; no Tolleys appear in the 1860 census for Brown County. ${ }^{7}$

Why would Bee, Tolley, Harris, Cain and many others locate their land grants in an area still entirely unsettled and still controlled by the implacable Comanches? Without specific knowledge of their motives it should be pointed out that by the mid-1840s most of the desirable large tracts east of the Texas settlement line had already been claimed, or were in the process of being claimed, by other grantees. And after 1845, when Texas was annexed by the United States, the prospects that immigration would increase, and that the settlement line would move rapidly westward, were good. Thomas Harris, who earned a fifty percent return on his investment when he bought and then sold the Ross tract in an eight-month period, had done well by himself. William Beasley, who bought the property from Harris but held onto it for several years, quite likely did much better.

Settlers began trickling into the area in 1856 , the same year that the Texas state legislature created Brown County. By all accounts the first permanent settler in the county was Welcome W. Chandler, who moved there with his family and a few slaves in July 1856; they settled on the east side of Pecan Bayou a few miles from present-day Camp Bowie. Later that year J. H. Fowler

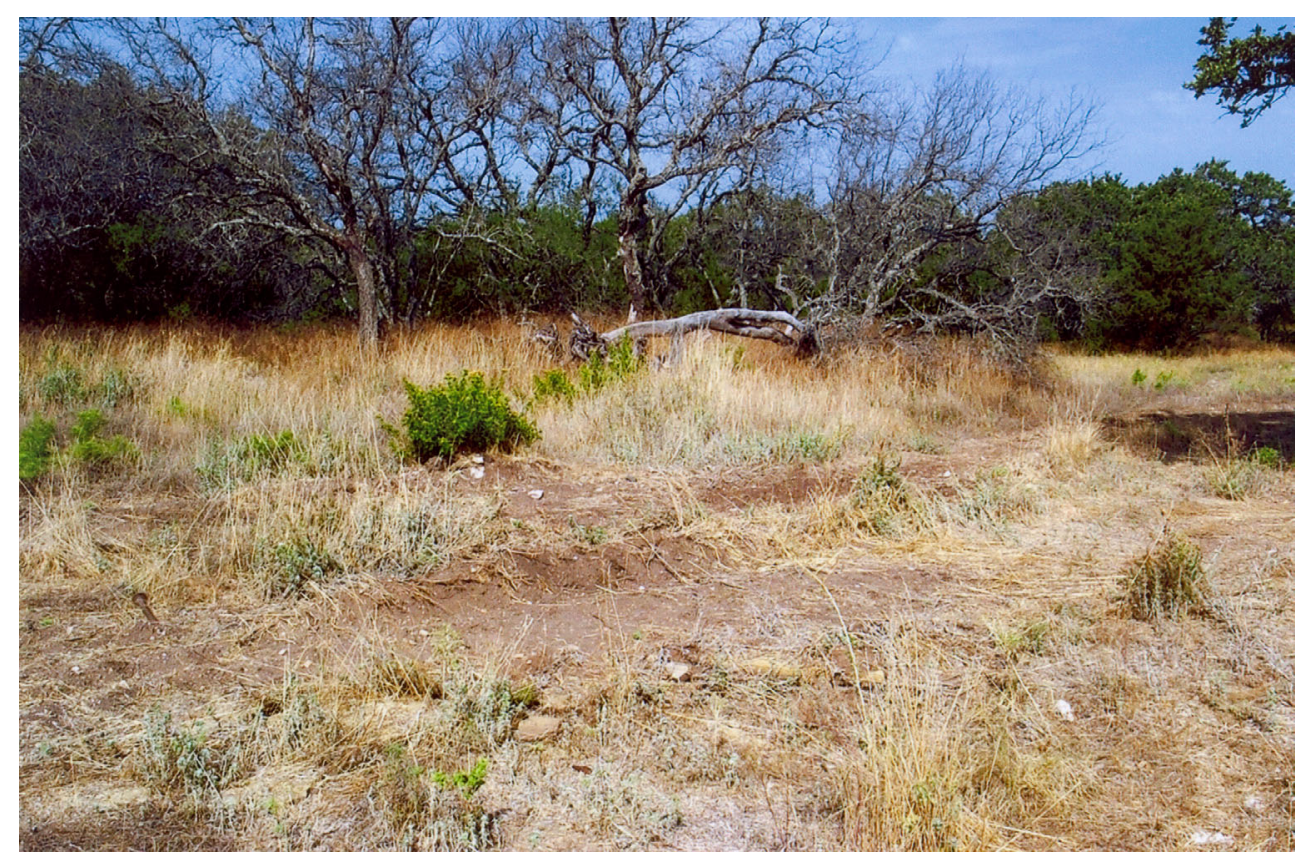

Figure 6. Fresh tank tracks at site 41 BR290 (historic farmstead). Photo by John Leffler, 2001. 


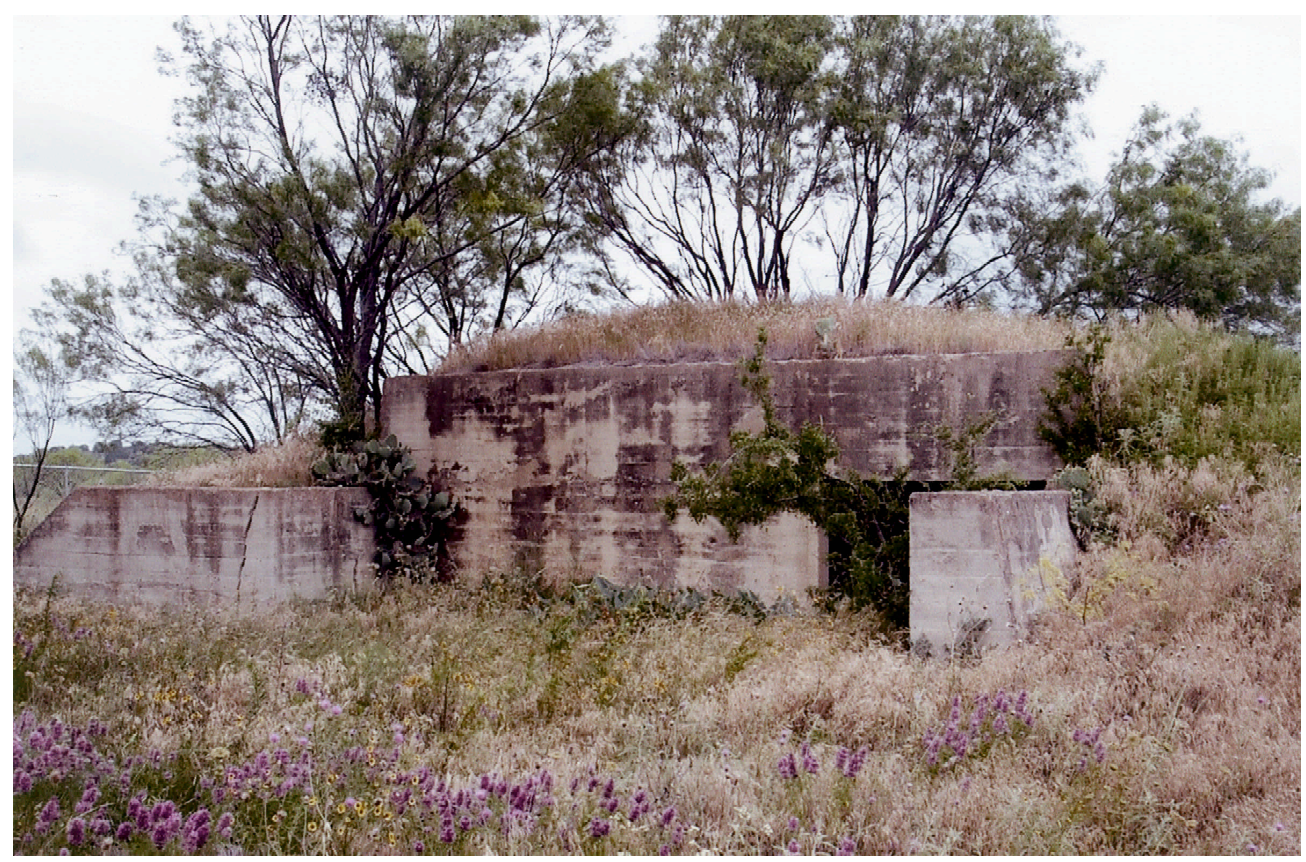

Figure 7. The bunker at site 41BR299, southern elevation. Photo by John Leffler, 2001.

arrived with the county's first herd of cattle, and several other settlers, including the families of David Hanna, Ambrose Bull, and Samuel Coggin, moved in at about the same time. Brownwood, the county seat, was established in 1857. By 1858 there were maybe fifty families in the Brown County area, and more were arriving all the time. ${ }^{8}$ As the area began to fill up, more properties were surveyed and claimed.

With the approval of the state legislature, in 1858 Kerr County surveyed and claimed a number of quarter-league and half-league tracts in south-central Brown County; sales of these lands would help support the development of Kerr County's school system. One of these tracts, Survey 277, would later be associated with historical site 41BR477. ${ }^{9}$ That same year another tract (associated with historical sites 41BR299 and 41BR290) was surveyed by the heirs of Thomas H. Roberts. Roberts had joined the Texas revolutionary army in January 1836, and may have belonged to a unit led by James Bowie. Roberts died at the Alamo on March 6, 1836. Because he had given his life to the revolution, Roberts' heirs were entitled to an extraordinarily large first-class land grant $-1,920$ acres- which they surveyed and claimed in the southern sections of what is now Camp Bowie. The tract was patented to "The Heirs of Thomas Roberts" in 1861. It is not clear whether any of these heirs actually settled on the property, but they may have. The 1860 manuscript census for Brown County shows a family farm headed by Archebald (age 42) and Nancy (age 42) Roberts living in the general vicinity of Brownwood. Their household included seven minors, one of whom was named Thomas. ${ }^{10}$

By 1860, according to the U.S. Census, there were 244 people living in Brown County. At least ninety percent of the households in the county adhered to the same pattern: husband and wife born in southern states such as Georgia, Mississippi, Tennessee, or Alabama; small children born in Texas. Though a number of men declared themselves to be farmers on the manuscript census, the agricultural census did not count any farms in the county at all, and only 91 acres in the county were classified as "improved." Many of the men referred to themselves "stock raisers" or "stock keepers," but the census listed only about 2,000 head of cattle, 57 horses, 4 mules, and 40 oxen. In 1860 Brown County was on the edge of the western frontier. ${ }^{11}$ 


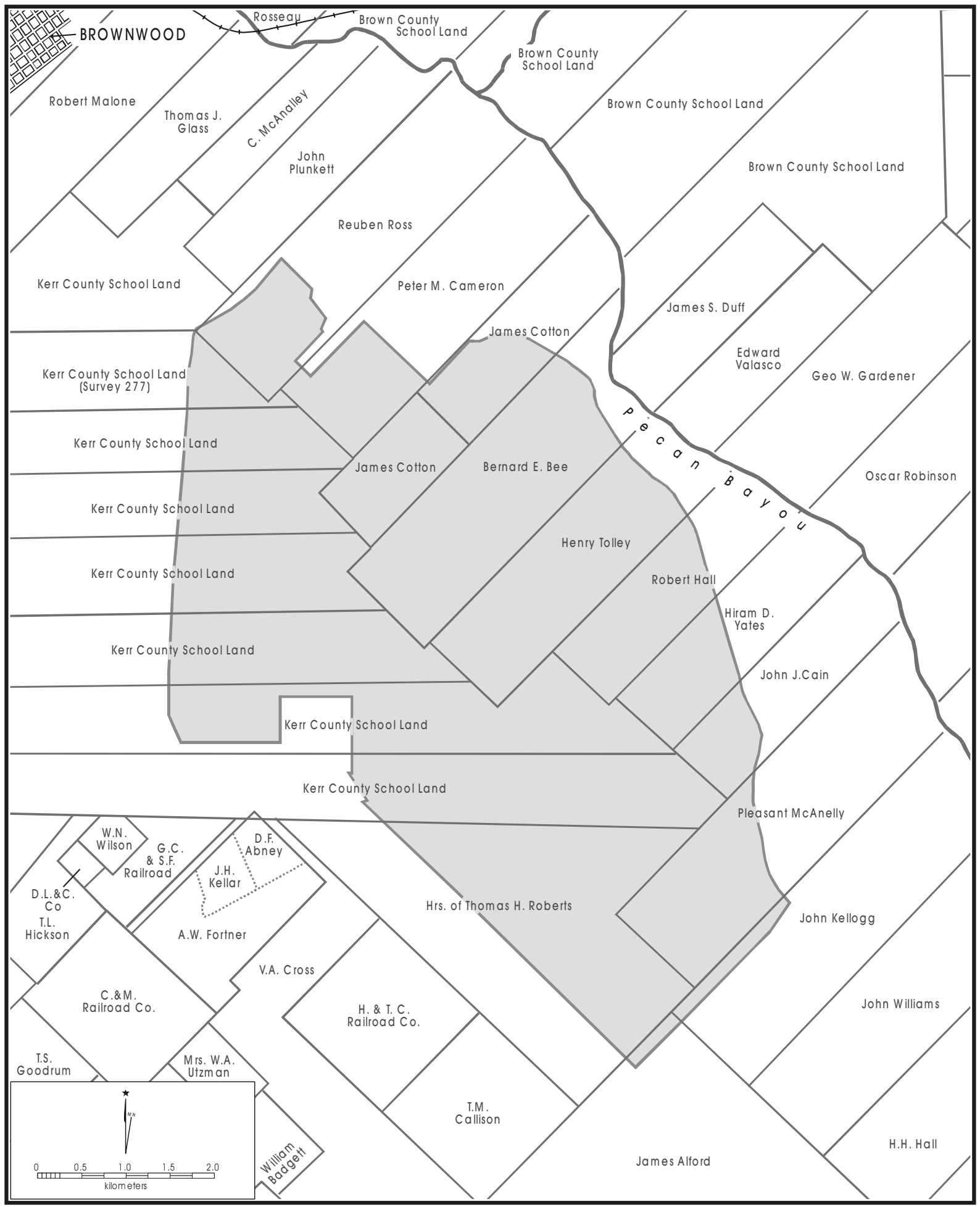

Figure 8. Land grants in the Camp Bowie area. Shaded area depicts current boundary of Camp Bowie. Locations of sites discussed in text are as follows: 41BR227 - Bernard E. Bee and Henry Tolley surveys; 41BR266 and 41BR477 - Kerr County School Survey 277; 41BR270 - Reuben Ross survey; 41BR290 and 41BR299 - Heirs of Thomas H. Roberts survey; 41BR438 - James Cotton survey. Adapted from 1944 Brown County land grant map, Texas General Land Office. 


\section{The Development of Brown County and the Camp Bowie Area, 1861-1900}

Dislocations occasioned by the onset of the Civil War and Indian raids deterred settlement for more than a decade after Brown County was formed. Comanches began raiding settlements in the area in the late $1850 \mathrm{~s}$, and though a small Texas Ranger detachment was based near Brownwood for most of the Civil War, the attacks, which sometimes culminated in vicious fights between settlers and the Comanches, continued throughout the 1860s. As late as 1870 only 544 people lived in Brown County, and only twentytwo farms had been established. ${ }^{12}$

Before the arrival of large numbers of farmers, most of the county was a huge prairie; pecan and mesquite trees grew along creeks and ridgetops but most of the area, including what is now Camp Bowie, was covered with stirrup-high bluestem and gamma grass. Despite the Comanche threat and general lawlessness during the 1860 s and early 1870 s, a number of cattlemen -the Coggin brothers, W. L. Parks, and J. J. Driskill-moved into the area and grazed their herds on the open range. The Coggins, who ranked among the most prominent cattlemen in central Texas, ran their stock across the prairie south of Brownwood (and quite possibly on land that is now Camp Bowie). The Brown County tax assessor counted almost 44,000 cattle in the county in 1869 , almost 48,000 cattle in 1874, and about 53,000 in 1879 . For a number of years after 1876, longhorns from other parts of the state also passed through the region on their way to northern and western markets. The cattle trail entered the county at its southeastern corner and then proceeded up the east bank of Pecan Bayou, crossing the stream a couple miles southeast of Brownwood and passing near or through the northern sections of present-day Camp Bowie. ${ }^{13}$

The last Comanche raid in Brown County occurred in 1874, and as the Indian threat receded settlers began to move into the area in ever-increasing numbers. The county's population rose to 8,405 in 1880 , to 11,421 in 1890 , and to 16,019 in 1900 . The overwhelming majority of the new settlers were white Southerners, born either in Texas or other southern states; in 1890, only 114 African-Americans lived in Brown County.

Many of the newcomers established farmsteads, either as owners or tenants. In 1870 there had been only 22 farms in the county, but there were 1,206 by $1880,1,396$ by 1890 , and over 2,000 by 1900 , when almost 114,000 acres in the county were classified by the agricultural census as "improved." Many farmers planted corn, oats and wheat, but cotton quickly became the county's most important crop. In 1900 , almost 46,000 acres in the county were devoted to the fiber. ${ }^{14}$ Although the number of cattle in the county remained fairly stable throughout the late nineteenth century (almost 39,000 head were counted in 1900), by 1890 it was clear that the area's economy and social fabric were much different than just ten years earlier. The days of the great cattle drives were over; more and more old ranches were being cut up into smaller tracts for farms and stockfarms, and as the population increased concentrated towns had begun to emerge. No communities were established within the boundaries of present-day Camp Bowie, but by 1900 there were a few nearby.

The most important of these was Brownwood, the county seat, which was about four miles northwest of present-day Camp Bowie (Figures 9 and 10). In the early 1870s Brownwood had been a tiny hamlet consisting of only a log courthouse, two stores, and five dwellings, but by 1877 it had grown to include three churches, a bank, several stores and saloons, and a cotton gin. Another, much smaller community-Indian Creek- also emerged. Indian Creek was established in 1876, and by 1879 it had a post office, two stores, and a cotton gin. By that time there was also a road leading southeasterly from Brownwood that crossed Willis Creek and then branched into two routes: one ran along the eastern periphery of present-day Camp Bowie on its way to Austin; the other ran southwesterly toward Indian Creek (See Figure 10). ${ }^{15}$

Another town, Empire City, was platted in 1873 on the James Alford survey (immediately south of present-day Camp Bowie) by the Great Western Land and Immigration Company. The company bought three hundred acres of land "valueless except for grazing purposes," subdivided the property into thousands of 25-by-100 foot lots, and then conducted an elaborate promotional campaign aimed at investors in northern states. Great Western's advertisements for lots in "Empire City" depicted the place as a bustling town with crowded streets and wharves piled high with cotton. But in fact, though many lots were sold to credulous investors, "Empire City" never existed at all; it was a land fraud scheme pure and simple, and a very profitable one at that. ${ }^{16}$

Brownwood grew rapidly after 1885 , when the first train of the Gulf, Colorado and Santa Fe Railroad entered the town; and in 1892 the Fort Worth and Rio Grande line extended 


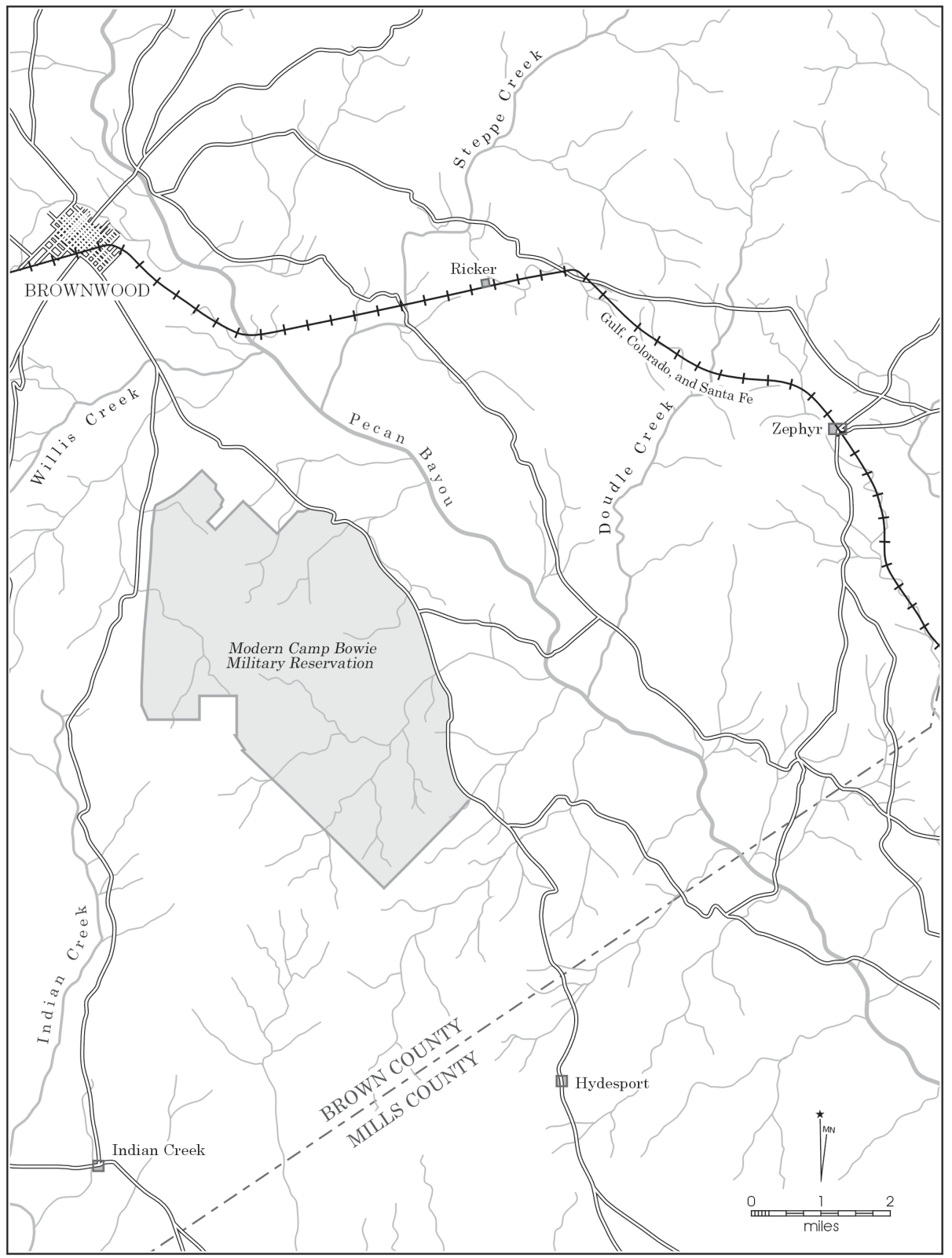

Figure 9. South-central Brown County in 1887. Adapted from 1887 USGS map.

its tracks there. By 1900 Brownwood's economy centered around the cotton industry; in addition to the town's sixteen cotton gins, it also boasted the West Texas Compress Company and a cotton oil mill. ${ }^{17}$ Meanwhile two new small communities were emerging in the vicinity of present-day Camp Bowie: Dulin, a farming and ranching community named after its founder Thomas S. Dulin, had a post office by 1896 , and Elkins, located on the Brownwood-Austin road about a mile southeast of present-day Camp Bowie, had a post office by 1906 (See Figure 10). A handful of rural schools were also established in the area south of Brownwood during this period; children living in the presentday Camp Bowie area may have attended the Willis Creek School, which was open by 1881 and still existed as late as 1908, or the Chapel Hill School, which also was operating by 1881 and stayed open into the 1930 s. $^{18}$ 


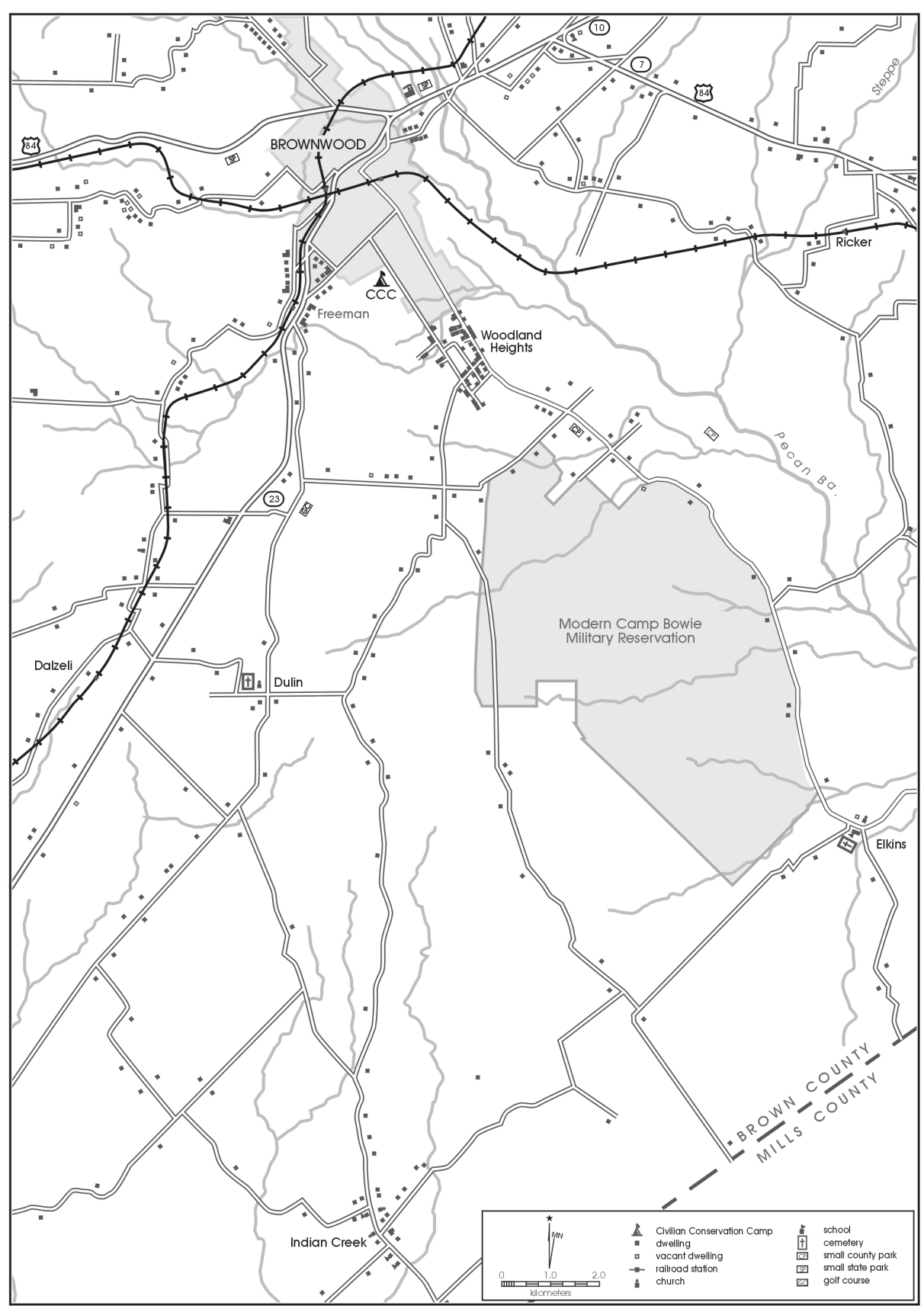

Figure 10. South-central Brown County in 1936. From Texas Department of Highways and Transportation map of Brown County, 1936.

The first known settler in the area presently occupied by Camp Bowie was D. H. Mosely, who established a farm on the Henry Tolley survey at least as early as 1876 . "Mosely's Farm," as it was designated on a contemporary map, was located near the stone wall at historical site 41BR227; the wall runs along the boundary between the Henry Tolley and Bernard Bee surveys. Mosely owned 340 acres in that vicinity in 1880 , and by 1883 he had enlarged his property to 351 acres. The wall at 41BR227 is actually located on land that belonged to Mosely's neighbor, Jonathan C. Yates, who by the 1890s owned 700 acres in the Tolley survey; his spread was known as the "J. C. Yates Farm and Ranch." It is not known how long Yates lived on the property, but he might very well have built the wall while working to clear a 
field in the area. By 1897 Yates and his wife Lace had apparently moved to Kentucky, and in November of that year they sold their 700-acre "farm and ranch" for $\$ 6,000$ to Ammit West, a resident of Brown County. ${ }^{19}$

Probably by the late 1870 s, and certainly by the early 1880 s, other land grants in the Camp Bowie area had also been cut up into smaller holdings and quite possibly settled, developed, and at least partly cultivated. By 1880 the Ross survey (associated with historical site 41BR270, a stone wall) for example, was already divided among four different landholders -William McCullough, B. F. Phillips, J. S. Adler, and J. W. Witt. Witt's holding -only 42 acres-was not nearly large enough for a ranch but sufficient for a hardscrabble farm if the land was flat and cultivable. By 1883 the Ross survey was divided among five landholders; J. F. Jackson, the newcomer, owned only 60 acres. The James Cotton survey was also sold during this period. This 320 -acre property associated with 41BR438 (another stone wall) was owned by S. E. Lacy at least as early as 1882 ; Lacy may very well have built the wall when clearing a field in the area. ${ }^{20}$

Not all of the land grants in the Camp Bowie area were cut into smaller parcels during this period. The 1,920-acre Heirs of Thomas Roberts tract (associated with the farmstead at 41BR290 and the WW II bunker at 41BR299), for example, remained intact and undivided. But many tracts were being divided, and all of the properties examined for this study changed hands, sometimes several times, during the late nineteenth century. (The Heirs of Thomas Roberts tract was sold to one R. B. Wilson in 1883.) The increasing demand for land in the Camp Bowie area during this period was reflected in rapidly rising land prices. S. E. Lacy's 320 acres, for example, were appraised for tax purposes at $\$ 400$ (or $\$ 1.25$ per acre) in 1882 ; at $\$ 1,100$ (about $\$ 3.40$ per acre) in 1886 ; and at $\$ 1,400$ (about $\$ 4.40$ per acre) in $1889 .{ }^{21}$

By 1900 Brown County, including the land occupied by present-day Camp Bowie, was much different than it had been only thirty years before. The era of the open range and the great cattle drives had come and gone. Ranching remained an important element of the local economy, mainly because many acres in the area were not suitable for cultivation. But most of the Camp Bowie area had already been cut up into relatively small landholdings of a few hundred acres or sometimes much less, and farmers were growing crops where they could.

\section{Brown County and the Camp Bowie Area, 1901-1940}

During the first few years of the twentieth century Brown County continued to develop along the same lines it had since the early 1880s: more immigration led to increases in population, the creation of more farms, and increasing cotton production. Between 1900 and 1910 the number of people living in the county jumped from about 16,000 to almost 23,000 ; the number of farms rose from 2,044 to 2,741 ; and acres in cotton almost doubled, rising from about 46,000 to almost 83,000 . The U.S. agricultural census counted almost 174,000 "improved" acres in the county in 1910, and more than 182,000 in 1920. Like many large landholdings in the county, some of the properties in the Camp Bowie area were divided up during this period. By 1917, for example, Ammit West had sold all but 231 acres (the property associated with historical site 41BR227) of the 700-acre parcel in the Tolley survey he had purchased from J. C. Yates back in 1897. By 1921, the Tolley survey had been cut into six different properties. When the remnants of the old Coggins ranch, the last of the county's big ranching operations, were divided and sold in the mid-1920s, one writer observed in an article entitled "Progress in Brown County" that:

The cackle of the hen and the grunt of the hog replace the whoop of the cowboys....The dairy cow is largely replacing the beef animal, and sheep and goats are taking increasingly important places. The day of the small ranch and the diversified farm instead of the wide range has finally arrived in Brown County. ${ }^{22}$

The fact is, however, that while the day of the "wide range" was over (and had been for some time), by the mid-1920s the heyday of farming in Brown County had passed too. For almost thirty years cotton had been the most important crop grown in the area; in 1908, local farmers produced almost 44,000 bales of cotton, more than in any previous year. But in 1909 boll weevils began to infest cotton fields in Brown County, and production dropped dramatically only 11,384 bales were produced that year. By 1915 a number of cotton gins in the area had closed down. Though local farmers planted more and more acres in cotton between 1915 and 1919, hoping that the weevil "scourge" would pass, their efforts yielded less and less product; droughts in 1917 and 1918 made matters worse. In 1918 the county's farmers produced only 1,048 bales of cotton. ${ }^{23}$ 
Many farmers began to plant alternative crops, especially oats and wheat, to replace the lost cotton, but grains were not well-suited to the sandy soils that prevailed in most of the county, including much of the Camp Bowie area. There the decline of cotton led many to turn to more livestock production. The number of cattle in the county increased and, especially during the 1920s, tens of thousands of sheep and Angora goats were introduced to the county's pasturelands. While many farmers were able to survive the transition away from cotton, others could not. A number of farmers moved out of the county, hoping to escape the weevil on fields farther west; by 1920 Brown County's population had dropped to 21,682. After the arrival of the boll weevil the number of farms in Brown County steadily declined, dropping from 2,741 in 1910 to 2,303 in 1920. The beginning of the Great Depression in 1929 led to a sharp drop in prices for crops and other commodities and by 1940 only 2,119 farms were left in the county. ${ }^{24}$

These trends may help to explain why land in the Camp Bowie properties examined for this study changed hands so often between 1920 and 1940. With few exceptions, ownership of the properties in the Tolley survey, for example, had remained stable during the 1910s. But of the six people who owned land on the Tolley survey in 1921, Ammit West was the only one who still owned property there in 1940, and he probably had never lived on his land. ${ }^{25}$

The 153-acre Subdivision 25 of Kerr County School survey 277 (associated with historical sites 41BR477 and 41BR266) also had multiple owners between 1917 and 1940. The entire tract was owned, and probably occupied, by S. B. Cannon until the 1920s. In 1922, perhaps because he was experiencing financial difficulties, Cannon mortgaged the property to the Union Central Life Insurance Company for $\$ 6,997$, and shortly thereafter transferred the land to Claude and Opal Hurlbut. By 1925, however, the Hurlbuts had moved to Lubbock, and that year they subdivided their Brown County property and sold 52 acres (the land associated with historical sites 41BR477 and 41BR266) to K. H. Boyd, a farmer, who with his wife Gracie, had been living in the vicinity since at least 1911; the remaining 101 acres changed hands twice over the next six years. Thus by 1940, when Camp Bowie was created, nobody living on Subdivision 25 had been there very long; K. H. and Gracie Boyd, who still owned and lived on their land, were among the relatively few old-timers in the immediate area. ${ }^{26}$

The 1,830-acre tract (associated with historical sites 41BR290 and 41BR299) in the Heirs of Thomas Roberts survey also changed hands during this period. In May 1927 J. H. Fry purchased the land from J. J. and Lillie Durham; he established a residence there, ran the property as a stockfarm and was still living there in the late 1930s. ${ }^{27}$

Of the Camp Bowie properties studied only the 320 -acre Cotton survey tract associated with historical site 41BR438 remained in the hands of the same family throughout the late nineteenth and early twentieth centuries. As mentioned previously, by 1882 this land was owned by S. E. Lacy, who apparently settled there and very possibly built the stone wall and other improvements that still exist on the property. Lacy and his wife Effie had at least three children, Frank, Will, and Margery; by the 1910s Frank and Will owned and farmed several properties in the Camp Bowie area. After S. E. died about 1908, Effie became full owner of the Lacys' 320-acre Cotton tract, and Frank and Margery (neither of whom ever married) apparently lived with their mother on the property and helped her run the place; they were still living with her there in 1938. Will and his wife Vera seem to have lived on another property the brothers owned nearby. ${ }^{28}$

Brown County's agricultural economy had been hurt by the decline of cotton, but the onset of the Great Depression made matters much worse. In 1934 almost 1,300 families representing about 25 percent of the county's populationwere on the county's relief rolls and more than half of the county's farm families were certified to be eligible for work relief programs. Various New Deal agencies helped local farmers to get through. In 1934 the Agricultural Adjustment Administration (AAA) paid farmers and ranchers in the county more than $\$ 200,000$ for cattle and sheep slaughtered by the AAA, and in 1935 farmers in the area were paid more than $\$ 560,000$ to keep cropland out of cultivation. Two Civilian Conservation Corps camps were established in Brown County in the mid-1930s, providing needed work for some men and cash for their families (see discussion below); and after 1935 hundreds of farmers in the county benefited from a federal program that gave them cash in return for their cooperation in soil conservation projects. ${ }^{29}$

With the possible exception of Ammit West, who lived in Brownwood and leased his property to a local stockfarmer, landowners in the Camp Bowie area seem to have struggled through the years of the Great Depression. By 1936 Effie Lacy was several years in arrears on her county taxes which, at that time, amounted to less than a dollar per acre per year. Fortunately for Effie, her daughter Margery lent her the $\$ 1,356$ she needed to lift the tax lien that had been placed on her land, or the property might have been seized. 
Effie continued to live on her stockfarm, but in return for Margery's help she later transferred the property to her daughter. Many other local farmers, including K. H. Boyd and J. H. Fry, saved their properties from repossession by refinancing their farms with low-interest loans funded by a New Deal agency, the Federal Farm Mortgage Corporation. ${ }^{30}$

While the Frys, the Boyds, and the Lacys managed to hold on to their properties during the Depression, they were by no means prosperous and probably never had been. The Lacys, for example, lived in a small ( $24 \times 30 \mathrm{ft}$.) house of "cheap" construction "in fair shape." Their home, built in 1900 , had no plumbing; a fireplace was their only heating, and oil lamps their only source of illumination. To support themselves in 1936 the family had a three-acre garden, 30 acres devoted to cotton, and 20 acres planted in "corn and cane"; their other 265 acres were given over to pasture for livestock. The Frys lived in an equally small (26 x $28 \mathrm{ft}$.) house of "cheap" construction with no plumbing, heated by a wood stove, and lighted by oil lamps. To support themselves they grew oats on 45 acres and raised livestock on the rest of their land. Details on the Boyds' homestead aren't available, but the family's real property, including their house and its outbuildings, was valued at less than a dollar an acre for tax purposes in 1936. These properties seem to have been fairly typical of the Camp Bowie area during the 1930s: the area then was sparsely populated and undeveloped, and most of the people living there were operating on the fringe of profitability. According to a study of Brown County's economy conducted in the late 1930s, Justice Precinct 7, which included most of present-day Camp Bowie, was one of the poorest areas in the county. ${ }^{31}$

\section{Check Dams and the Civilian Conservation Corps in the Camp Bowie Area}

A number of check dams and other improvements to retard soil erosion have been found in the area that is now Camp Bowie, including the check dams at historical site 41BR270 and the bridge/dam at 41BR477 (see Figures 4 and 5). These may have been built by the Civilian Conservation Corps (CCC) during the 1930s, but given the extensive soil conservation work completed in the county during the 1930s and early 1940s, and because the CCC's records for this area seem to have been destroyed, it is difficult if not impossible to ascertain the origins of these structures.
The Civilian Conservation Corps, one of the earliest New Deal programs, was created in 1933 partly to relieve unemployment during the Depression and partly because President Franklin Roosevelt was genuinely interested in conserving the nation's natural resources and keeping Americans connected with nature. The program, officially initiated in April of 1933, hired young men aged 18 to 25, and some World War I veterans, for $\$ 30$ a month to work on conservation projects across the United States. With President Roosevelt intensely interested in the program -he insisted that he would have to personally approve the location of every CCC camp- the CCC grew quickly. By July 1, 1933, it had already established 1,300 camps employing 250,000 men, including 25,000 veterans. By 1935, it was running 2,514 camps and employed 502,000 men. $^{32}$

For most of its existence (1933-1942) the CCC focused on three major priorities: soil conservation, reforestation and building infrastructure for state and national parks. In 1935 there were 27 CCC companies working in Texas state parks, and another 70 camps, employing 14,000 men, working on soil conservation projects in the state. Two CCC camps operated in Brown County during the 1930s. One, Camp 3818 , composed mostly of veterans from the county, was established in 1934 and was based just outside of Brownwood until 1936 (see Figure 10). Its work was based on soil conservation projects on private properties in Brown County, and may have built the check dams and other structures on present-day Camp Bowie. The other, Camp 849 , was a more typical CCC camp which employed young men, most of whom were not from the area. Camp 849 was based at Lake Brownwood, and between 1936 and 1941 it kept busy building cabins, roads, lodges, trails and other facilities for what is now the Lake Brownwood State Recreation Area. ${ }^{33}$

Though the CCC was actively engaged in soil conservation projects in Brown County during the mid-1930s, it is seemingly impossible to determine which Brown County properties the agency worked on during that period. The Brownwood office of the USDA's Natural Resources Conservation agency has no records relating to that time, they seem to have been destroyed when the CCC's records were selectively archived. As noted earlier, federal loans granted in the area were often conditioned on the borrower participating in soil conservation activities. By the early 1940s, tens of thousands of acres in the Brown County area were involved in such projects in cooperation with local soil conservation districts. ${ }^{34}$ 
After September 1939, when the Germans invaded Poland, the role of the CCC began to change; many in Congress and elsewhere demanded that the camps should include military training for those enrolled in the program (which was, after all, supervised by the U.S. Army). By September 1940, the educational mission of the agency had shifted to promote skills that would prepare CCC workers for defense work or military service. In December 1941, after the attack on Pearl Harbor, a number of CCC camps were moved to military reservations to help prepare for the war to come..$^{35}$ One of these was Company 3818 , the veterans' company which had operated in Brown County. In 1941 it was reassigned or reorganized at a camp located inside the newly-created Camp Bowie (Figure 11) ${ }^{36}$ It is possible but unlikely that this company worked on soil conservation projects; most probably, it was working to help build the camp's roads and infrastructure which, at the time, were being built at a furious pace.

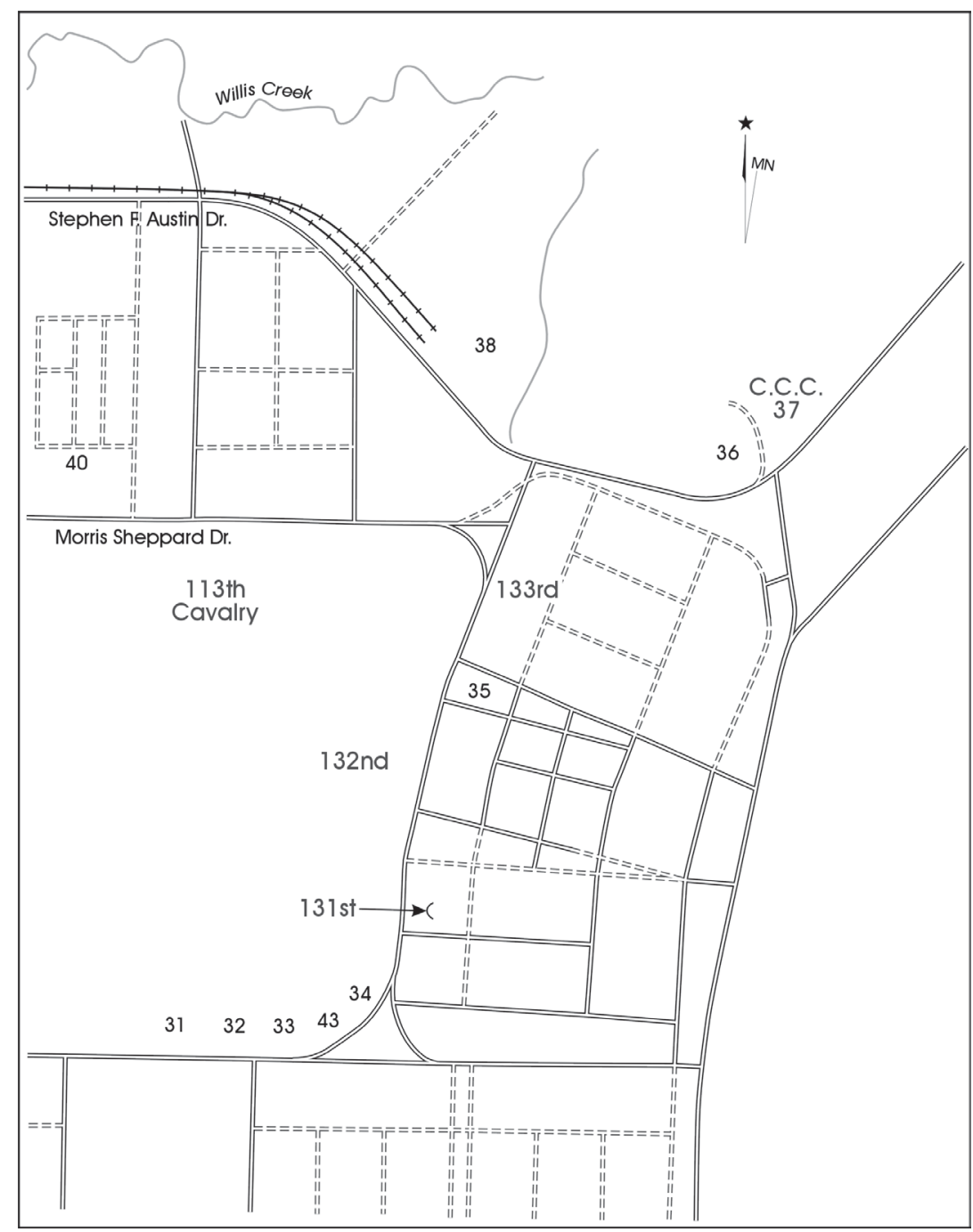

Figure 11. Map showing the location of the CCC camp in the northeastern section of the cantonment area at Camp Bowie, 1941-1942. From map distributed by Brownwood Chamber of Commerce. 


\section{The Creation, Growth, and Decline of Camp Bowie}

Brownwood businessmen first attempted to attract a National Guard training camp to their area as early as 1923, when rumors circulated that the Texas National Guard was going to abandon Camp Mabry and relocate its headquarters. Nothing came of that attempt. But in the spring of 1940 , after German armies had overrun much of western Europe, the Brownwood Chamber of Commerce and local officials were already working out a proposal that they hoped would convince the U.S. government to establish a training center in Brown County. The original plan was for a camp stretching across 61,000 acres south of Brownwood that would include a 2,000-acre campsite, infantry and artillery firing ranges, and a 28,000-acre maneuver area. The city of Brownwood would lease the land necessary for the project, and re-lease the property to the government. ${ }^{37}$

In July a delegation from the city presented the proposal to Major General H. J. Brees, commander of the Eighth Army Corps at Fort Sam Houston in San Antonio. As the Army evaluated the proposal various committees of the Brownwood Chamber of Commerce scrambled to acquire leases on more than a hundred different parcels of land; when two landowners in the projected camp area were reluctant to lease, the Chamber arranged for a private loan to buy the properties. Ultimately the Chamber acquired the rights to over 88,000 "sparsely settled" acres, which, when the camp was created, were leased to the government for a dollar per acre per year. ${ }^{38}$

On September 5, 1940 the Brownwood Bulletin reported that the camp would be established. Originally the Army had planned to build a training facility capable of holding an 18,000-man infantry division, but after September 16, when Congress passed the Selective Training and Service Act which created the first peacetime draft in American history, plans for the camp expanded dramatically. Construction began right away. About 16,000 workers were hired for the project and despite some early delays, most of the first construction phase was completed by early February, 1941. In just a matter of months, contractors had built over 8,000 buildings and 52 miles of roads on the site and had installed more than 300,000 feet of water lines, 464,000 feet of gas lines, and 725,000 feet of electrical wire. As Texas Parade magazine put it, Camp Bowie quickly became "a modern city, with all of the conveniences of a present-day community"39 (Figures 12-16).

The first troops, elements of the 66th Division, Texas National Guard, arrived at the camp in November, and within four months they had been joined by other Texas Guard units and the 113th Cavalry of the Iowa National Guard; by March 1941 almost 30,000 troops were in place. The last landowners who lived in the original camp area left in the middle of February, when infantry and artillery troops began to use live ammunition at the camp's firing ranges. A number of landowners were still permitted to run livestock on their properties, however, and on at least some of the tracts the Army was required to repair damages to fences and other improvements. ${ }^{40}$ By December 1941, when the United States entered World War II, tens of thousands of men had already trained for combat at Camp Bowie.

In August 1942, the Army announced that the camp would be expanded to 120,000 acres, partly to accommodate its new role as a training center for armored units, and indicated that the properties it had leased for the camp up until that

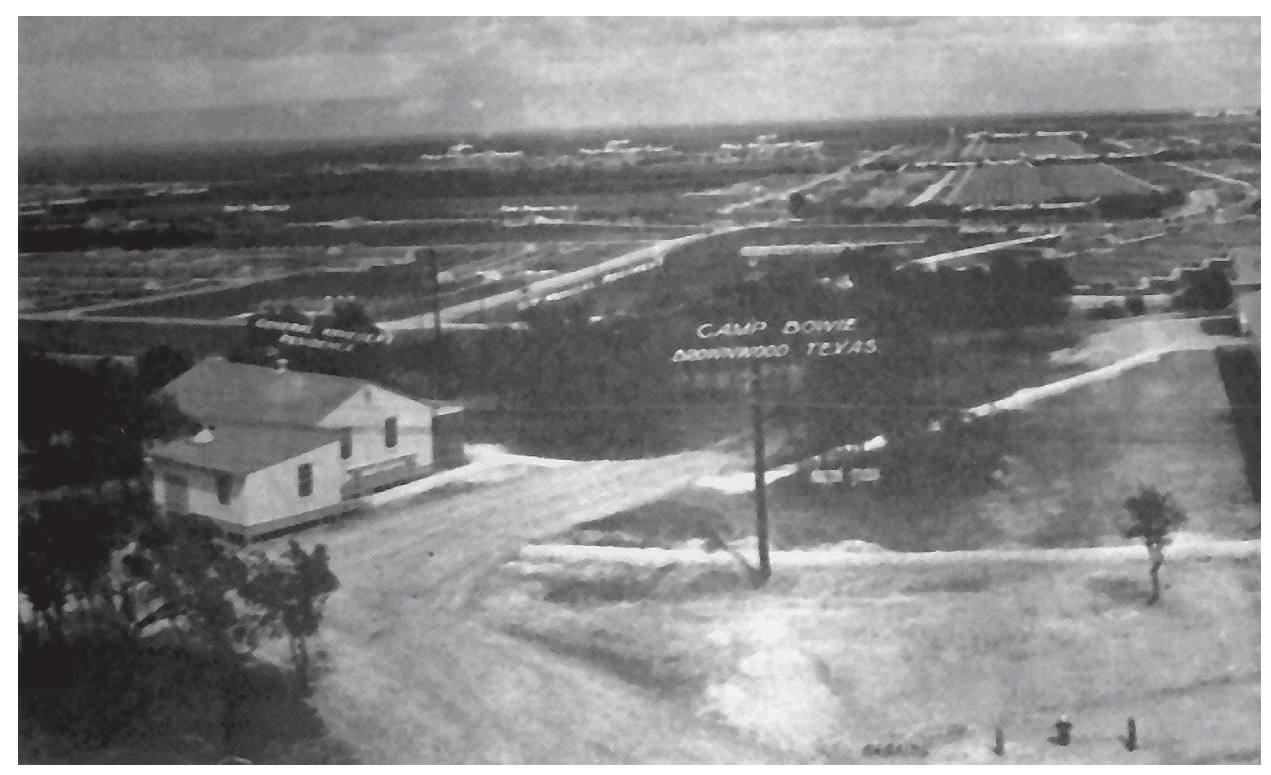

Figure 12. Panorama of Camp Bowie during World War II, looking south - the commandant's house is on the left. From "Heritage Scrapbook II" calendar, 1981. 


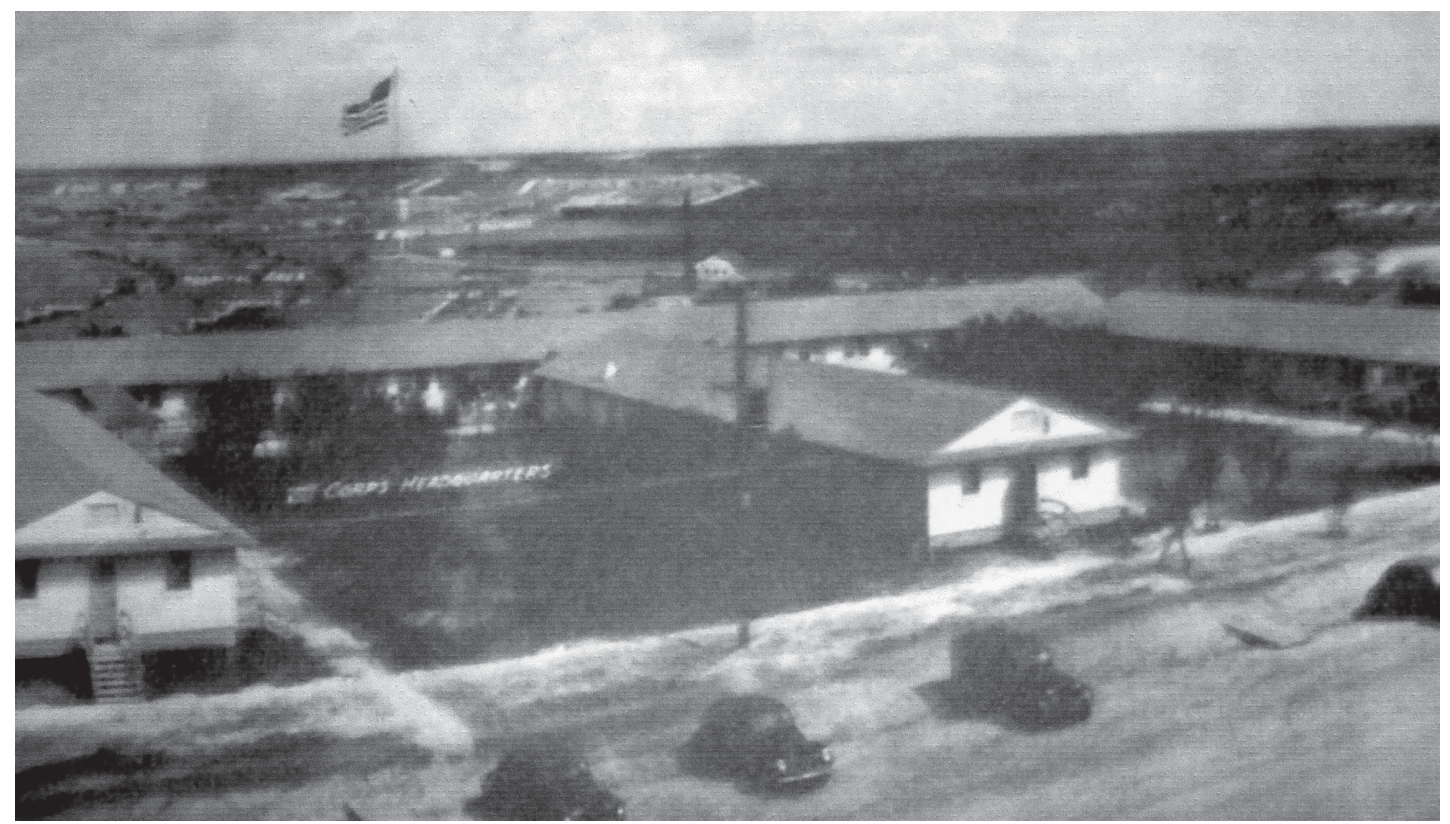

Figure 13. Camp Bowie headquarters during World War II. From "Heritage Scrapbook II" calender, 1981.

time would now be purchased. For many owners in the original camp area, this was not in itself bad news. In fact, a group of them, including J. H. Fry, had been asking for some time that the government buy their lands; training operations had often destroyed fences and other improvements on the properties, and the Army had been slow to make repairs. According to Gene Mattox, the manager of the Brownwood
Chamber of Commerce, the demands of this group had helped to trigger the Army's decision to buy the land and enlarge the camp. While the leases had apparently been given voluntarily, however, now the government was prepared to condemn the entire 120,000 acres it wanted; and the enlargement of the camp would entail the displacement of more than a hundred families. ${ }^{41}$

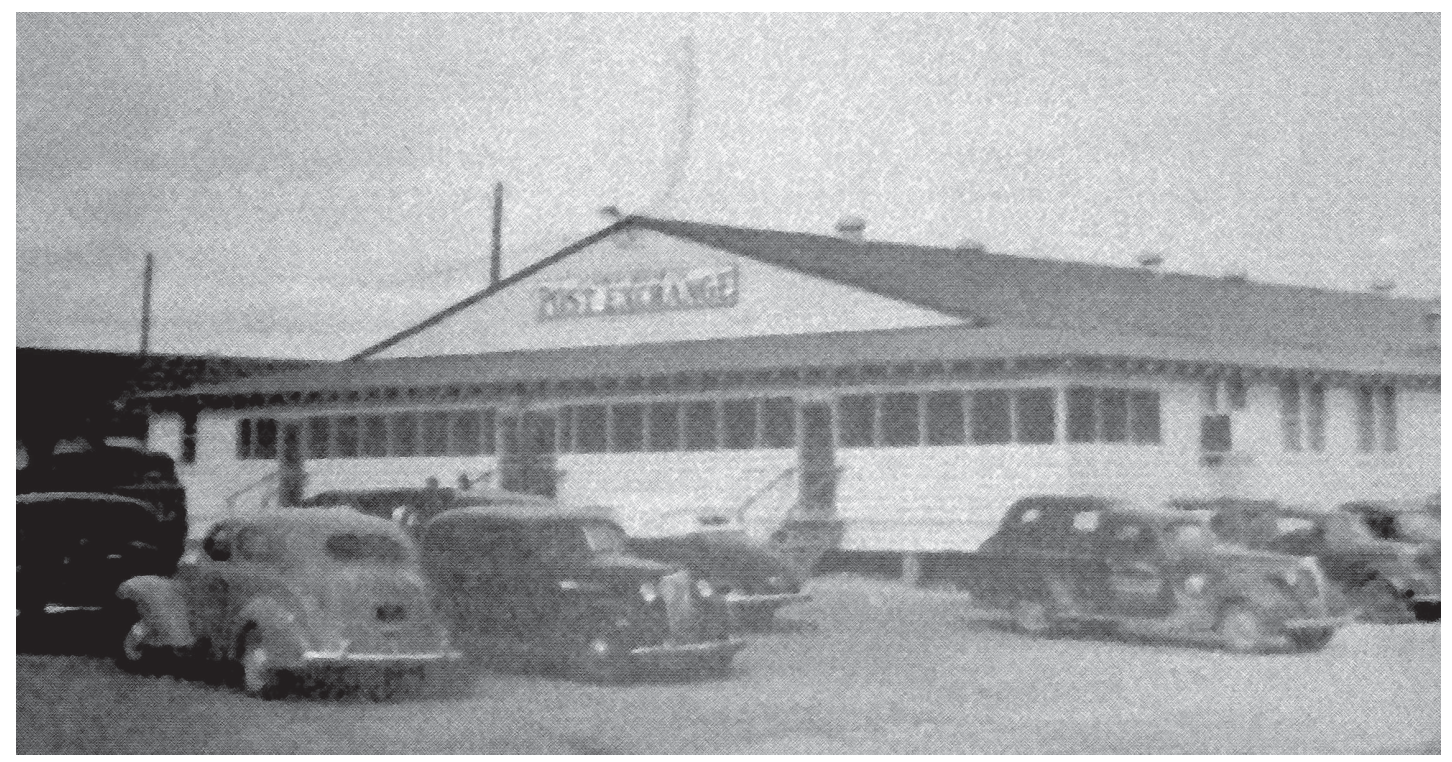

Figure 14. A post exchange at Camp Bowie during World War II. From "Heritage Scrapbook II "calendar, 1981. 


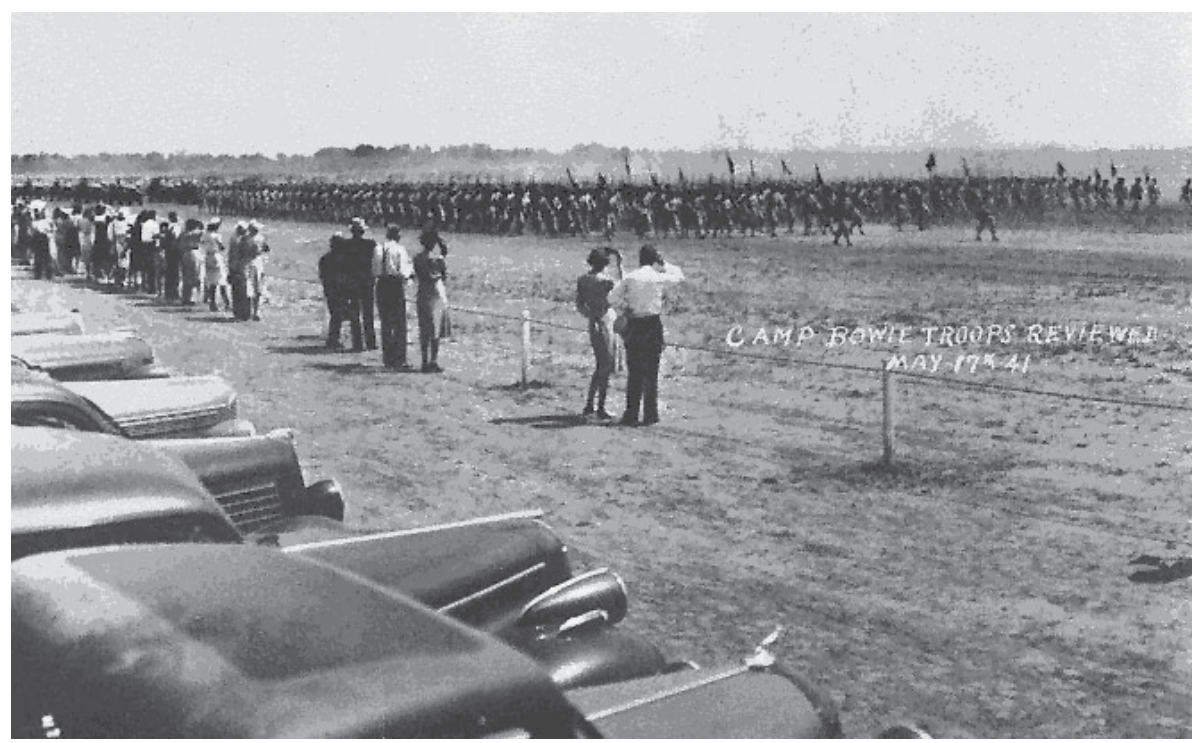

Figure 15. Troops at Camp Bowie march in review, May 1941. From "Heritage Scrapbook II " calendar, 1981.

Almost as soon as the decision was announced a number of landholders unhappy with the prices the government was offering them for their properties formed a "Land Owners Association" to obtain better terms. As Owen Hall, the association's secretary, explained, the landowners were not trying to be uncooperative; they just wanted a fair price:

These landowners, along with other Americans, are giving their fair share of men to the armed forces; they are likewise contributing labor and money toward the winning of the war. Besides this and above what is asked of the average citizen, they are submitting uncomplainingly to a compulsory exodus from their homes, a matter of sentiment which goes deeper than the casual sale and purchase of land and houses.

Therefore, while there is demand from no landowner that the government pay him a premium for his property, there is a conviction that farmers and ranchers should receive for their holdings prices commensurate with the current price of land and improvements of similar quality. To expect less is incompatible to the spirit of citizens of a democratic society. ${ }^{42}$

On August 29, the Land Owners Association sent a delegation to Dallas to meet with officials at the Army Land Purchasing Office, but it is not clear what results, if any, the association received for its efforts. In September the federal government, acting on its authority under the War Purposes Act, filed condemnation suits against the properties involved; most people living there were given until the end of October to vacate their lands and, if they could, to move their houses. Some would have to leave as early as October 1. Prices for the properties would be determined later. As a result of the condemnations, three communities -Elkins, Indian Creek, and Jordan Springs- were "entirely depopulated." ${ }^{43}$

It is not clear what happened to all the people dislocated by the expropriations; according to one long-time county resident familiar with the area at the time, people "scattered all over the place." A big problem faced by many farmers and ranchers was that the arrival of the camp had driven property values in the area up, making it difficult if not impossible for landowners to buy comparable properties elsewhere in the county. As a spokesman for the Land Owners Association explained, "Many of us have diligently searched for other properties during the last few weeks, and all ranch and farming lands are at probably the highest premium this country has seen for many years, and most of us have found that properties of like kind and description to ours cannot be found at this time at any price." In late September, the Brown County USDA War Board offered to help landowners who were facing the October 1st deadline but were having trouble finding adequate housing, or having a hard time hiring trucks to move their belongings. ${ }^{44}$ 


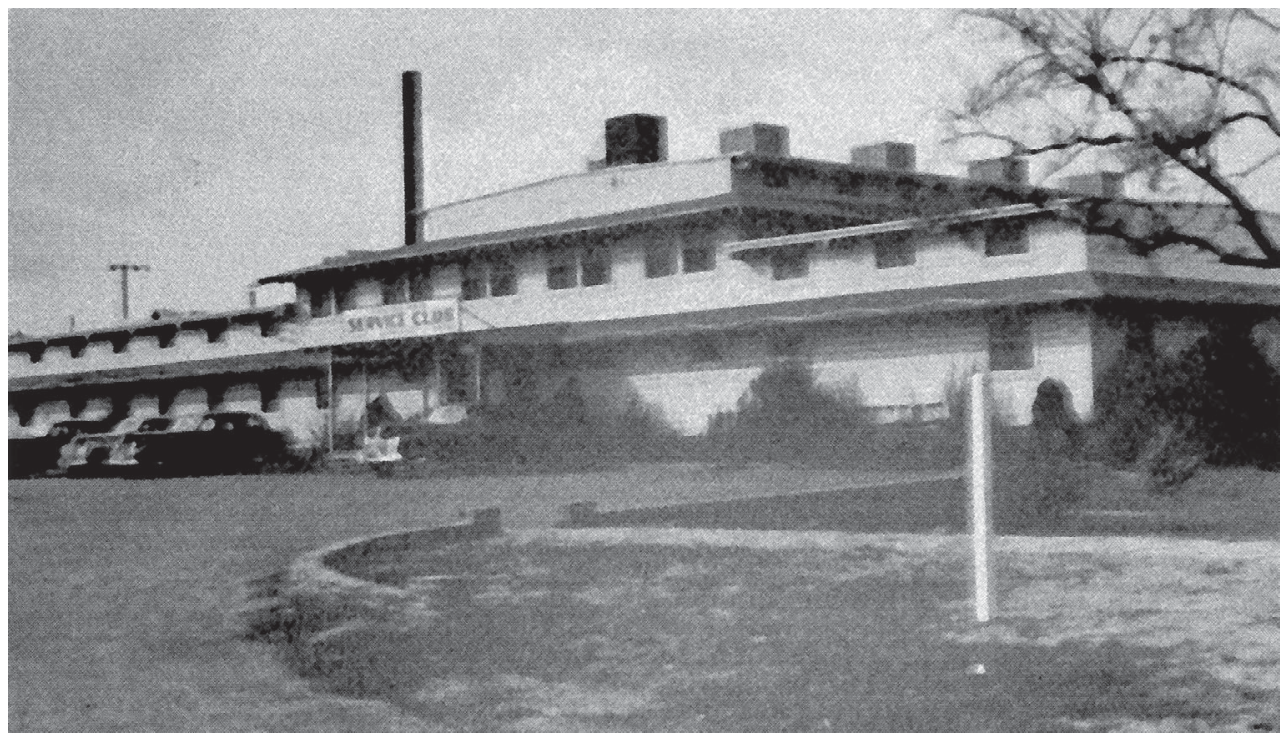

Figure 16. A service club at Camp Bowie during World War II. From "Heritage Scrapbook II " calendar, 1981.

Despite the difficulties they faced, some of the dislocated stockfarmers and ranchers were able to reestablish themselves on other properties in the county. J. H. Fry, for example, bought (for $\$ 3,115$ ) an 89-acre place just west of the new camp in December 1942; and K. H. Boyd bought 130 acres (for $\$ 2,737$ ) in the William Hays survey in November 1943. Others left the county, and a number of them moved to cities in Texas and elsewhere to work in aircraft factories and other defense plants. ${ }^{45}$

In time, Camp Bowie grew to be the largest World War II training facility in Texas. By 1945, the installation covered over 123,000 acres and could accommodate more than 45,000 troops at a time; in all, more than 200,000 men and women (the camp had a WACS component after 1943) had served or trained there (Figure 17). In addition to the National Guard units mentioned above, elements of the Eighth Service Command and of the Third, Fourth, and Eighth Army Corps served or trained in the camp; and in August 1943, a prisoner-of-war camp that could hold 3,000 men was established there. ${ }^{46}$

After Japan surrendered in August 1945, Camp Bowie had outlived its reason to exist. Because the camp had injected millions of dollars into the local economy, many local citizens hoped that the camp would be maintained in some form. But by September 1945 troops were already vacating the camp, and a few months later only a handful of soldiers were still stationed there. The camp was turned over to the War Assets Administration in January 1947 and over the next few years almost all of its buildings and facilities were sold. In some cases, former owners of land in the area reacquired their properties. On April 14, 1949, the federal government transferred 5,410.64 acres of the old camp to the Texas National Guard, stipulating that the property would be used "for the training and maintaining of civilian components of the armed forces of the United States of America." ${ }^{47}$ As of the date of publication of this report, the Texas National Guard still operates Camp Bowie as a training facility.

It is not clear when the ammunition bunker at historical site 41BR299 was built but dates scrawled on its inside walls indicate that it was probably part of the original camp built before 1942. Judging by the numerous items of graffiti (mostly the names of soldiers accompanied by dates and often the names of their hometowns) drawn on the inside of the bunker, it was used during and just after World War II by soldiers from across the northeastern and Midwestern United States. The earliest inscription, written in chalk on the southeastern wall of the bunker, reads " 8 ball C. Norberg Cambridge Minnesota 1941." Other examples: "PFC Makovich Redding PA 1944"; "Jim Potsfilio Mass 1945"; "Dominick Bemr[?]hal New Rochelle, NY November 22, 1947." One soldier from Auburn, New York did not leave his name but drew what is probably a crude self-portrait 
(Figure 18) ${ }^{48}$ The bunker is one of the last structures associated with the old World War II training camp that still exists on presentday Camp Bowie. Within the confines of the scope of this report it proved impossible to track down any of the soldiers who left their names there, but it would be interesting to do so. The spirit of their comments -sometimes earnest, occasionally playful, occasionally obscene- still seem to animate the bunker's interior, and calls us back to remember the humanity, and the sacrifices, of the men who made them.

\section{Summary}

The area encompassed by presentday Camp Bowie seems to have developed along the lines of the rest of south-central Brown County, but even more slowly and incompletely. Ranching and stockfarming defined the local economy. There is no evidence that any communities were ever established there (though some existed nearby), and by the mid1930s only one significant road cut into the area. In the late 1930s, before Camp Bowie was created, most of south-central Brown County was occupied by ranches

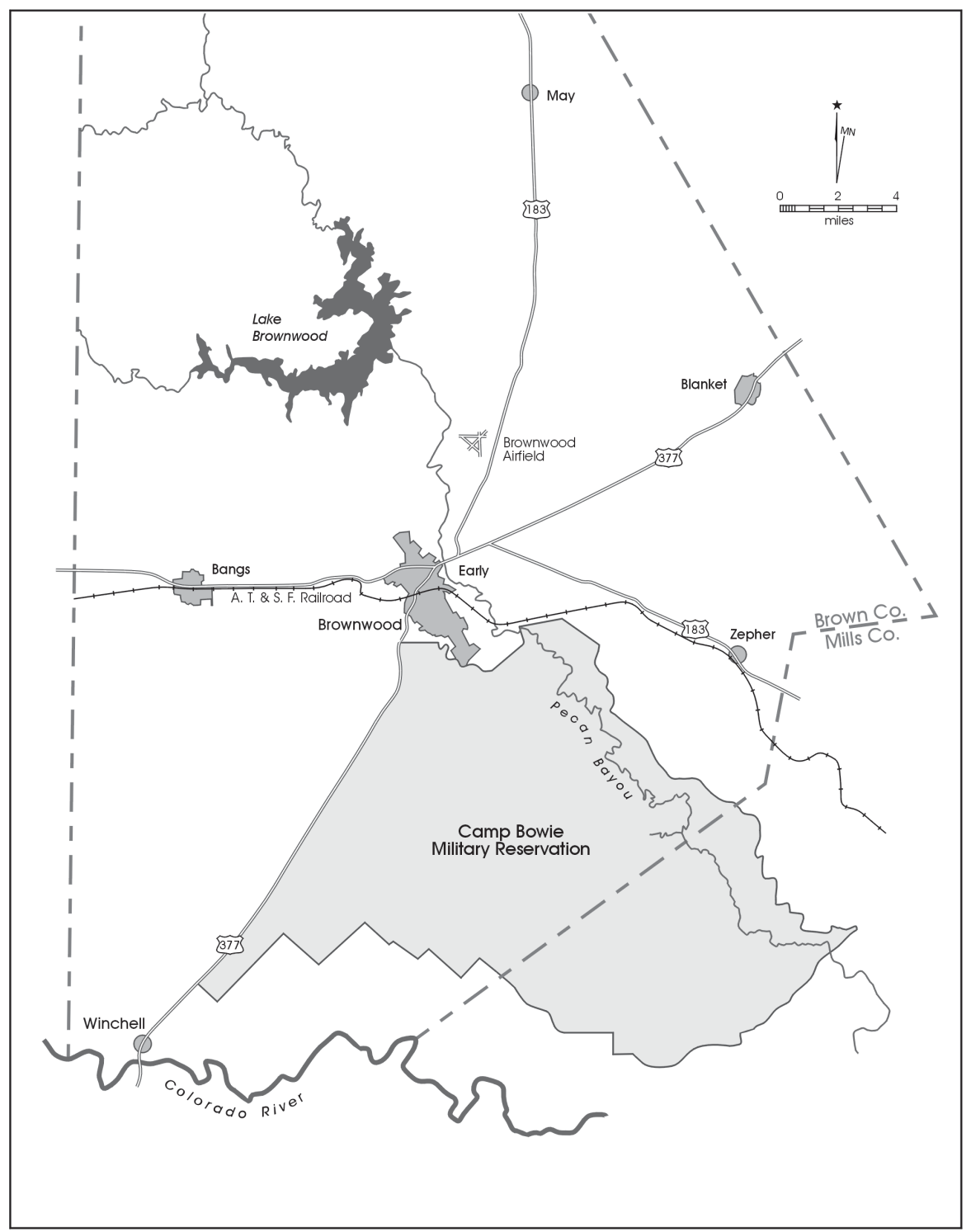

Figure 17. Camp Bowie in 1945. Adapted from Moneyhon 1967. and stockfarms. At that time the land that is now Camp Bowie, like the rest of south-central Brown County, was sparsely populated, and its ranchers and stockfarmers were just barely getting by. Agriculture had dominated the local economy since the 1850 s, when the area was first settled. In the 1860 s and 1870 s its grasslands attracted cattlemen; during and after the 1880 s thousands of farmers moved into the county.

During the Great Depression of the 1930s, the federal government offered help through the Agricultural Adjustment Administration, farm loan guarantees, and other New Deal programs. Two Civilian Conservation Corps

camps were established in Brown County; one of these, Camp 3818, worked with county landowners on soil conservation projects.

In 1940, local officials and boosters began to organize an effort to attract an Army camp to the area, hoping to stimulate the county's economy. The original Camp Bowie was deliberately placed in south-central Brown County partly because the area was sparsely populated but the camp's creation and, especially, its subsequent expansion led to the displacement of over a hundred families and the disintegration of three small communities. 


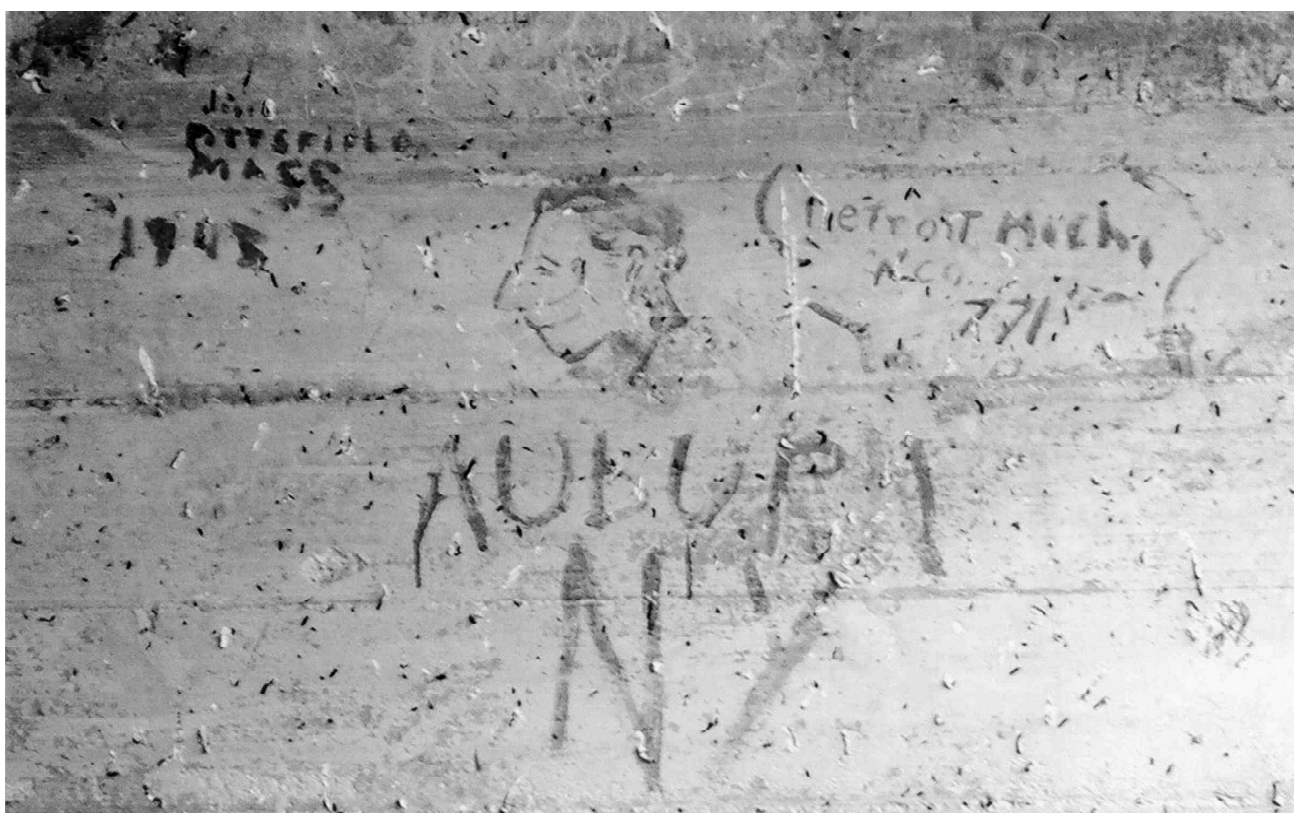

Figure 18. Graffiti from the interior of the bunker at site 41BR299. Photo by John Leffler, 2001.

In November 1946, after the war was over, the original Camp Bowie was decommissioned. Most of the camp's land was sold to the public, but the federal government retained control of several thousand acres. In April 1949, 5,411 acres of the original Camp Bowie were deeded to the Texas National Guard, which subsequently established its own training facility there.

During the mid-1990s, a study of Camp Bowie conducted by the Environmental Resources Management Branch of the Adjutant General's Department of Texas, identified a number of historical sites within the camp's boundaries (Wormser and Sullo-Prewitt 2001). These included sites 41BR227, 41BR438, and 41BR266, all of which are sandstone walls; sites 41BR270 and 41BR477, both of which contain check dams built to control erosion; site 41BR290, the remains of a farmstead; and site 41BR299, a bunker dating to the World War II era.

\section{$41 B R 227$}

Site 41BR227 is a sandstone wall that runs along the boundary of the Bernard Bee and Henry Tolley surveys. D. H. Mosely, one of the earliest settlers in the area, was operating a farm nearby at least as early as 1876 , but the wall itself is located on land owned by Jonathon Yates, who by the 1890 s was operating a 700 -acre stockfarm there and quite possibly built the wall. Yates sold the property to Ammit West. By the 1920s West had sold off most of the property, but he retained title to a 231-acre tract on which the wall was situated. West himself probably never lived on this tract, and there was no dwelling there in the 1930s; the property was leased out for grazing.

\section{$41 B R 438$}

Site 41BR438, another sandstone wall, is located on land originally granted to James Cotton. Cotton almost certainly never lived on the property, and sold it almost as soon as he surveyed it. C. A. Hopson and John Cain, the new owners, were probably land speculators and there is no evidence that either of them ever lived on the property. By 1882, the first year county land records are available, the land occupied by site 41BR438 was owned by S. E. Lacy, who may have built the wall while clearing a field in the area. This property was occupied by members of the Lacy family until it was acquired by the government for Camp Bowie. After S. E. Lacy died in about 1908, the land passed into the hands of his widow, Effie Lacy, who lived there with their children Frank and Margery. Like many stockfarmers living in the area, the Lacys lived in a small, inexpensively-constructed house without electricity or running water. In the 1930s most of their land was devoted to livestock, but they grew vegetables, cotton, corn, and cane on about fifty acres. 


\section{BR266}

Site 41BR266, another sandstone wall, is on Kerr County School Survey 277. Throughout the late nineteenth and early twentieth centuries the property was owned, and probably occupied, by S. B. Cannon. In the early 1920s, he sold it to Claude and Opal Hurlbut. The Hurlbuts lived on the tract only briefly if at all, however, and in 1925 they sold it to K. H. Boyd, a farmer who had been living in the general vicinity since at least 1911. Boyd and his wife lived on the property and operated a stockfarm there into the late 1930s.

\section{BR290}

Site 41BR290, once the site of a farmstead, is on the Heirs of Thomas Roberts survey. The 1861 survey remained intact and undivided until 1883 , when the heirs sold it to R. B. Wilson. In 1927 it was purchased by J. H. Fry, who operated a stockfarm there into the late 1930s. Like the Lacys, Fry ran livestock on most of his land, but he also grew crops; in the mid-1930s he devoted 45 acres to oats. His home, which may have been the farmstead at 41BR290, was small and inexpensively- constructed with no electricity or plumbing; by the late 1930s, it was in poor condition. By 2001 the site had been so seriously disturbed that very little evidence (aside from a cement cistern dating to the 1930s) of the old farmstead remained.

\section{$41 B R 270$ and $41 B R 477$}

Local tradition holds that the check dams and soil conservation structures at sites 41BR270 and 41BR477 were constructed by the Civilian Conservation Corps. It is quite possible, even probable, that they were; the construction techniques and styles are consistent with other projects built by the CCC during the 1930s and early 1940s. Two CCC camps operated in Brown County during the 1930s. One operated in construction improvements around Lake Brownwood; the other, Camp 3818, based just south of Brownwood, engaged in soil conservation projects. In 1941, Camp 3818 was moved to, or reorganized at, Camp Bowie.

Though the CCC was actively employed in soil conservation projects in Brown County during the mid-1930s, it proved impossible to determine which Brown County properties the agency worked on during that period. The Brownwood and Tyler offices of the USDA's Natural Resources Conservation Service have no detailed records related to Company 3818; the records seem to have been destroyed when the CCC's records were selectively archived. By the early 1940s, tens of thousands of acres on the Brown County area were involved in soil conservation projects separate from the CCC. It is possible, but unlikely, that CCC company 3818 worked on soil conservation projects at Camp Bowie when it was stationed there in 1941 and 1942. By that time, the CCC had shifted its focus from conservation to defense work and military training. Most probably, Company 3818 was working to help build the camp's roads and infrastructure, including, perhaps, the bridge/dam at $41 \mathrm{BR} 477$.

\section{BR299}

The munitions bunker at site 41BR299 was probably part of the original training camp built before 1942 and was used during and just after World War II. It is one of the few structures from the original camp that still exist. Of the seven sites examined for this study, 41BR299 is the best preserved and most significant. 


\section{Endnotes}

1 Tevis Clyde Smith, "The Dawn of Brown County," in Frontier's Generation (Austin: Texas State Historical Association: n.d.), p. 2; James C. White, The Promised Land: A History of Brown County (Brownwood, Texas: n.p., 1941), p. 6; John Leffler, "Brown County," in The New Handbook of Texas [hereafter cited as NHT ] (6 vols. Austin: Texas State Historical Association, 1996), 1:770.

2 T. R. Havins, Something About Brown: A History of Brown County, Texas (Brownwood, Texas: Banner Printing Company, 1958), pp. 9-10.

3 Bee land grant, dated February 14, 1846, and survey in Texas land grant records, Bastrop file B-407, Texas General Land Office [hereafter TGLO], Austin, Texas; Thomas W. Cutrer, "Bee, Bernard Elliot, Sr.," NHT $1: 457$.

4 Reuben Ross land grant file Bastrop B-863, Texas land grant records, TGLO; James Hays McLenden, "Ross, Reuben," NHT 5:689-690.

5 Reuben Ross land grant file Bastrop B-863, Texas land grant records, TGLO; Ralph Terry, comp., "Brown County, Texas 1860 Federal Census," U.S. Genweb Archives Census Project, at http:usgenweb.org/census. Except for sales and transfers noted in Texas land grant files, it is almost impossible to document many landholders in Brown County for thirty-five years after these 1846 land grants were assigned because all Brown County records dating before 1880 were destroyed in a courthouse fire.

6 Cotton land grant file, Bexar 3-366, Texas land grant files, TGLO; Bill Groneman, "Cain, John," NHT 1:891.

7 Tolley land grant file Bexar 2-256, Texas land grant files, TGLO.

8 Havins, Something About Brown, pp. 12-13.

9 Kerr County School Lands land grant file Travis 1-400, Survey 277, Texas land grant records, TGLO.

10 Heirs of Thomas Roberts land grant file Travis B-543, Texas land grant records, TGLO; Terry, "Brown County, Texas Census for Brown County," p. 3.

11 Terry, "Brown County 1860 Census"; John Leffler, comp., "Population and Agricultural Statistics for Brown County, drawn from U.S. Census reports, 1860-1980," in files of the Texas State Historical Association, Austin.

12 White, The Promised Land, pp. 18-30; Leffler, comp., "Population and Agricultural Statistics for Brown County."

13 Havins, Something About Brown, pp. 33-36; "Progress in Brown County," Farm and Ranch 44 (August 15, 1925), p. 15; A. R. Roessler, "Map of Brown County, Texas, Showing the Extent of All Public Surveys." (New York: The Texas Land and Immigration Company of New York, 1876), shows the Camp Bowie area to be entirely grassland during the mid-1870s.

14 Leffler, "Population and Agricultural Statistics for Brownwood County."

15 Mark Odintz, "Brownwood, Texas," NHT 1:780; Roessler, "Map of Brown County, Texas."

16 "Texas Fraud of '70s Has Faint Echoes," (San Antonio Evening News, April 17, 1933).
17 Mark Odintz, "Brownwood, Texas," NHT 1:780.

18 William Hunt, "Indian Creek, Texas," NHT 3:829; Jeanne C. Lively, "Dulin, Texas," NHT 2:723; Rachel Jenkins, "Elkins, Texas," NHT 2:825; Fields, Maudie J., "The Educational History of Brown County, Texas" (M.A. thesis, University of Texas at Austin, 1927), pp. 39, 40 and 50; Brown County School Superintendent's Report for 1908, in Brown County Superintendent's Reports, Box 4/23/234, Texas State Education Department Records, Texas State Archives, Austin; Leslie Thomas Griffin, "A Survey and Proposed Plan of Reorganization for the Schools of Brown County, Texas" (M.A. thesis, University of Texas at Austin, 1937), school district map following page 58. The Mosely School, another schoolhouse operating in Brown County in 1881, may have been associated with D. H. Mosely (see discussion in text) but I have not been able to confirm that.

19 Roessler, "Map of Brown County, Texas"; Tax Assessor's Abstract, Tolley survey, Brown County Tax Appraisal Office, Brownwood, Texas; Deed from J. C. and Lace Yates, to Ammit West, November 20, 1897, Brown County Deed Records [hereafter BCDR] 45:488-489, Brown County Courthouse, Brownwood, Texas. West's first name appears in various deeds and tax records sometimes as "Ammit" and sometimes as "Armmit."

20 Tax Assessor's Abstracts for Cotton and Ross surveys, Brown County Tax Appraisal Office.

21 Tax Assessor's Abstracts for Heirs of Thomas Roberts and James Cotton surveys, Brown County Tax Appraisal Office.

22 "Progress in Brown County," Farm and Ranch 44 (August 15, 1925), p. 15.

23 Leffler, "Population and Agricultural Statistics for Brown County"; Assessor's Abstract for the Tolley survey, Brown County Tax Appraisal Office; Havins, Something About Brown, pp. 92-94.

24 Havins, Something About Brown, pp. 94-99; Leffler, "Population and Agricultural Statistics for Brown County."

25 Assessor's Abstract for Tolley survey; according to Tax Assessor's sheets, 1936, for Ammit West tract, Brown County Appraisal Office, there was no house on the property at that time, and according to tax assessment records for the 1920s and 1930s in the office of the Brown County Clerk, Brown County Courthouse, West lived at 1511 Vine Street in Brownwood during that entire period.

26 Deed of Trust from Hurlbuts to Cannon, March 30, 1922, Brown County Trust Records [hereafter BCTR] 27:77; Deed of Trust from K. H. and Gracie Boyd to Federal Farm Mortgage Company, March 1, 1934, in BCDR 327:21, Brown County Courthouse; Brown County Assessor's Abstract for Subdivision 25. Brown County Birth records show that a female child (no name given) was born to K. H. and Gracie Martin Boyd on May 4, 1911; Boyd's occupation is listed as "farmer," and his address as "Brownwood R.F.D."

27 Deed from J. J. and Lillie Durham to Fry, May 23, 1927, BCDR 230:80; Deed of Trust from Fry to Federal Land 
Bank, Houston, Texas BCTR 43:183. Brown County Marriage Records in the Brown County Courthouse show that a J. H. Fry married Lena Bolt on January 4, 1906, but it is not clear whether or not this was the same J. H. Fry discussed above; county tax records going back to the early twentieth century show many Fry families in Brown County at that time.

28 Brown County tax assessment records for 1919 and 1938, Brown County Courthouse; Deed from Mrs. Effie Lacy to Margery Lacy, June 17, 1938, BCDR 313:40-41; Deed of trust from Frank, Will, and Vera Lacy to Ira Yates, BCTR 49:421.

29 Havins, Something About Brown, 157-160.

30 Deed of Trust from Fry to Federal Land Bank, Houston, Texas BCTR 43:183; Deed of Trust from Boyd to Federal Land Bank, Houston, BCTR 51:315 and BCDR 324:512; deed from Effie Lacy to Margery Lacy, June 17, 1938, BCDR 313:40-41; deed of trust from Effie Lacy to Margery Lacy, BCTR 52:433.

311936 tax assessment sheets for the Fry, Lacy, and Boyd properties, Brownwood County Tax Appraisal Office. Other conclusions based on review of tax assessment sheets for 1936 for other properties in the immediate vicinity; on the 1936 Texas Department of Highways and Public Transportation map which shows very few habitations in the area of present-day Camp Bowie; and map of distribution of purchasing power in Brown County in Griffin, "A Survey and Proposed Plan of Reorganization for the Schools of Brown County, Texas," p. 40 .

32 John A. Salmond, The Civilian Conservation Corps, 19331942: A New Deal Case Study (Durham, North Carolina: Duke University Press, 1967), pp. 24, 30, 35-37, 58.

33 Havins, Something About Brown, 159; CCC camp index records, USDA Natural Resources Conservation Service, Tyler, Texas; James Wright Steely, The Civilian Conservation Corps in Texas State Parks (Austin: Texas Parks and Wildlife Department, 1986), listing under "Lake Brownwood State Recreation Area."

34 "Soil Conservation Service Work Unit To Be Established at Goldthwaite Soon," (Brownwood Messenger, August 12, 1942); "Soil Service and Conservation Districts Plan Improvement on 16,827 Acres" (Brownwood Messenger, August 25, 1942).

35 Salmond, The Civilian Conservation Corps, pp. 197, 209

36 "Civilian Conservation Corps Camps, Nineteenth Period 1942," for Texas. My thanks to Jim Steely for this document, which he obtained at the National Archives, Washington, D.C. and passed on to me. See also James J. McEntree, "The CCC and National Defense," American Forests 46 (1940), pp. 309-310, 340.

37 Havins, Something About Brown, pp. 160-161; Tessica Martin, "Brownwood, Texas in World War II" (typescript, 1966, in Brownwood Public Library), pp. 6-7.

38 Martin, "Brownwood, Texas in World War II," pp, 6-7; "Army Heads Order Firing Areas at Bowie Evacuate" (Dallas News, January 30, 1941).
39 Havins, Something About Brown, pp. 161-162; "From Mesquite Brush to Army Camp," Texas Parade vol. 6, no. 8 (January, 1942), pp. 16-17.

40 Havins, Something About Brown, pp. 162-163; "Firing to Start on Bowie Ranges, Residents Warned" (Dallas News, February 9, 1941).

41 "Purchase of Camp Bowie and 120,000 Acres By U.S. Army Culminates Movement Launched in July, 1941" (Brownwood Bulletin, August 9, 1942).

42 "Landowners Send Committee to Dallas Meeting" (Brownwood Bulletin, August 29, 1942); Havins, Something About Brown, p. 162.

43 "The Government Will Take Over 120,000 Acres Of Land In Brown And Mills Counties" (Camp Bowie Blade, September 25, 1942); "County War Board Offers Services to Aid Relocation of Area Landowners" (Brownwood Bulletin, September 25, 1942); Havins, Something About Brown, p. 162.

44 Telephone conversation with Cullen Perry of Brownwood, Texas, June 7, 2001; "Landowner Unit To Meet Camp Buying Problems” (Brownwood Bulletin, August 16, 1942); "County War Board Offers Services To Aid Relocation of Area Land Owners" (Brownwood Bulletin, September 25, 1942).

45 Deeds from E. C. and Viola Alford to Boyd, November 8 and 16, 1943, BCDR 324:512; Deed from J. P. McLeod et al., to J. H. Fry, December 19, 1942, BCDR 320:478479; telephone conversation with Cullen Perry.

46 Martin, "Brownwood, Texas, in World War II," pp. II12; "Camp Bowie," NHT 1:929.

47 Havins, Something About Brown, pp. 168-169; Correction Deed Without Warranty from the United States of America to the Texas National Guard Armory Board, September 16, 1954, in historical files at AGTX-EV, Camp Mabry, Texas.

48 Author's personal inspection of the bunker, July 2001; historical site description for 41BR299, in files at AGTXEV, Camp Mabry. 


\section{References Cited}

Burleson, S. J.

1950 Rural Population Trends and Their Educational Implications in Brown County, Texas, for 1940 to 1950. Unpublished M.A. thesis, University of Texas at Austin.

Camp Bowie

1996 The New Handbook of Texas, edited by R. Tyler, 1:929. Texas State Historical Association, Austin.

Cutrer, T. W.

1996 Bee, Bernard Elliot, Jr. In The New Handbook of Texas, edited by R. Tyler, 1:457. Texas State Historical Association, Austin.

Fields, M. J.

1927 The Educational History of Brown County, Texas. Unpublished M.A. thesis, University of Texas at Austin.

From Mesquite Brush to Army Camp

1942 Texas Parade, vol. 6, no. 8, pp. 16-17, 25.

Griffin, L. T.

1937 A Survey and Proposed Plan of Reorganization for the Schools of Brown County, Texas. Unpublished M.A. thesis, University of Texas at Austin.

Groneman, B.

1996 Cain, John. In The New Handbook of Texas, edited by R. Tyler, 1:891. Texas State Historical Association, Austin.

Havins, T. R.

1958 Something About Brown: A History of Brown County. Texas. Banner Printing, Brownwood, Texas.

Hunt, W.

1996 Indian Creek, Texas. In The New Handbook of Texas, edited by R. Tyler, 3:829. Texas State Historical Association, Austin.

Jenkins, R.

1996 Elkins, Texas. In The New Handbook of Texas, edited by R. Tyler, 2:825. Texas State Historical Association, Austin.

Leffler, J.

1996 Brown County. In The New Handbook of Texas, edited by R. Tyler, 1:769-771. Texas State Historical Association, Austin. 
Leffler, J. (compiler)

n.d. Population and Agricultural statistics for Brown County, drawn from U.S. Census reports, 1860-1980. Manuscript on file at the Texas State Historical Association, Austin.

Life in CCC Camp.

1935 Farm and Ranch, vol. 54, no. 24. 15 December:18.

Lively, Jeanne,

1996 Dulin, Texas. In The New Handbook of Texas, edited by R. Tyler, 2:723. Texas State Historical Association, Austin.

McEntree, J. J.

1940 The CCC and National Defense. American Forests 46:309-310, 340.

McLenden, J. H.

1996 Ross, Reuben. In The New Handbook of Texas, edited by R. Tyler, 5:689-690. Texas State Historical Association, Austin.

Martin, T.

1967 Brownwood, Texas in World War II. Unpublished manuscript on file in Brownwood Public Library, Brownwood, Texas.

Moneyhon, C. H.

1967 Post-war Adjustments in Brownwood, Texas, August 1945-August, 1946. Unpublished college term paper on file in Brownwood Public Library, Brownwood, Texas.

No Reds in the CCC

1933 Farm and Ranch, vol. 52, no. 22. 15 November:1.

Odintz, M.

1996 Brownwood, Texas. In The New Handbook of Texas, edited by R. Tyler, 1:780. Texas State Historical Association, Austin

Progress in Brown County

1925 Farm and Ranch, vol. 1, no. 44. 15 August:15.

Roessler, A. R.

1876 Map of Brown County, Texas, Showing the Extent of All Public Surveys. The Texas Land and Immigration Company of New York, New York.

Salmond, J. A.

1967 The Civilian Conservation Corps, 1933-1942: A New Deal Case Study. Duke University Press, Durham, North Carolina. 
Smith, T. C., Jr.

n.d. From the Memories of Men. T. C. Smith, Jr., Brownwood, Texas

Smith, T. C.

n.d. Frontier's Generation: An Enlarged Version of the Original Book. n.p., Brownwood, Texas [?].

Spence, R. G.

n.d. The Nice and Nasty of Brown County. Banner Printing Company, Brownwood, Texas.

Steeley, J. W.

1986 The Civilian Conservation Corps in Texas State Parks. Texas Parks and Wildlife Department, Austin.

Terry, R. (compiler)

[1860] Brown County, Texas 1860 Federal Census. U.S. Genweb Archives Census Project. Accessed at $<$ http:usgenweb.org/census $>$.

White, J. C.

1941 The Promised Land: A History of Brown County. Brownwood Banner, Brownwood, Texas.

Wormser, A. J., and S. Sullo-Prewitt

2001[1999] Cultural Resources Inventory of Camp Bowie, Brownwood, Texas. Archaeological Survey Report, No. 317, Center for Archaeological Research, The University of Texas at San Antonio; The Adjutant General's Department of Texas, Texas Army National Guard, Austin, Texas.

\section{Newspaper Articles}

Dallas News

1941 "Army Heads Order Firing Areas at Bowie Evacuated." January 30.

1941 "Firing to Start on Bowie Ranges, Residents Warned." February 9.

\section{Brownwood Bulletin}

1942 "County War Board Offers Services To Aid Relocation of Area Land Owners." September 25.

1942 "Landowner Unit To Meet Camp Buying Problems." August 16.

1942 "Landowners Send Committee to Dallas Meeting." August 29.

Brownwood Messenger

1942 "Soil Conservation Service Work Unit To Be Established at Goldthwaite Soon." August 12.

1942 "Soil Service and Conservation Districts Plan Improvement on 16,827 Acres." August 25.

Camp Bowie Blade

1942 "The Government Will Take Over 120,000 Acres Of Land In Brown And Mills Counties." September 25.

San Antonio Evening News

1933 “Texas Fraud Has Faint Echoes.” April 17. 


\section{Government Records, Documents, Maps, and Publications}

Brown County School Superintendents' Reports, Texas State Education Department Records, Texas State Archives, Austin.

Brown County Birth and Death Indexes, Brown County Courthouse, Brownwood, Texas.

Brown County Deed Records, Brown County Courthouse, Brownwood, Texas.

Brown County Tax Appraisal Abstracts, Brown County Tax Appraisal Office, Brownwood Texas.

Brown County Tax Appraisal Sheets for 1936, Brown County Tax Appraisal Office, Brownwood, Texas.

Brown County Tax Assessment Books, 1906-1939, Brown County Courthouse, Brownwood, Texas.

Brown County Trust Records, Brown County Courthouse, Brownwood, Texas.

Civilian Conservation Corps. Directory [of] Civilian Conservation Corps Camps, Nineteenth Period. Office of the Director, Civilian Conservation Corps, May 1942.

Texas State Department of Highways of Public Transportation. Highway map of Brown County, 1936.

U.S. Army Corps of Engineers. Ownership Map, Camp Bowie, July 1943. In Camp Bowie historical map collection, AGTX-EV, Camp Mabry, Texas.

U.S. Geological Service. Topographical map of San Saba [Texas] quadrangle, 1887.

U.S. Geological Service. Topographical map of Indian Creek and Bowser [Texas] Quadrangles, 1983.

Wirth, Conrad Lewis, Civilian Conservation Corps Program of the U.S. Department of the Interior March 1933 to June 30, 1943. A Report to Harold Ickes. Washington, D.C., 1944

\section{Miscellaneous Sources}

Brown County Scrapbook, Boxes 3L106, 3L107, Center for American History, University of Texas at Austin.

"Camp Bowie." Map with accompanying text and photos, distributed by the Brownwood Chamber of Commerce.

"Heritage Scrapbook II." Calendar (with photos of Camp Bowie during World War II) produced by Southwest State Bank, Brownwood, Texas, 1981. In Brownwood Public Library, Brownwood, Texas.

Vertical file for Brown County, in Center for American History, University of Texas at Austin.

\section{Personal Interviews}

Telephone conversation with Cullen Perry of Brownwood, Texas, June 7, 2001.

Telephone conversation with Ronnie Lappe, June 8, 2001. 
Appendix A

Site Descriptions 


\section{BR227}

41BR227 is a stone wall dating to between 1856 and 1941. It was constructed on a level terrace in a marshy area within the existing tank training area, with an unnamed intermittent tributary to Devil's River about $150 \mathrm{~m}$ to the north.

The wall runs in a northeast-southwest direction, is $370 \mathrm{~m}$ long and 1 to $2 \mathrm{~m}$ wide, and extends across the terrace with an elevation ranging between 393 and $396 \mathrm{~m}$ amsl. Most of the wall has been badly disturbed by clearing and grubbing to create a target area for tank artillery training. Artificial berms, which are used to hold targets, have been constructed with bulldozers, further destroying the wall so that it now appears as a loose, linear pile of sandstone rubble. Although its alignment is visible, the wall is mostly destroyed.
No prehistoric components were observed in the field, despite 80 percent ground surface visibility and several repeated visits to the stone wall during various surveys from 1994 to 1997. Yet two prehistoric artifacts found in the lab may have come from the site. Their disposition is questionable; they could be either 1) isolated finds from near the wall, or 2) miscataloged. They are a Late Archaic Pedernales point (Collins 1995; Johnson and Goode 1994) and a Late Archaic Ensor point (Turner and Hester 1993).

\section{BR266}

This is a historic stone wall (Figure A-1), possibly a field boundary dating to the early 1900 s, running parallel to a north-south trending fence and gravel road along the base of Travis Peak. Approximately $110 \mathrm{~m}$ long and oriented on

It is constructed of drylaid sandstone blocks probably procured from the nearby bluffs to the west and the southwest. The stones do not appear to be cut, just roughly broken or used as they were found. The individual stones range in size from approximately 15 to $30 \mathrm{~cm}$ in diameter, and the more intact segments of wall have stones stacked to a height of about $60 \mathrm{~cm}$.

The wall separates the original boundary between the tracts granted to patentees Henry Tolley (1847) and Bernard Bee (1841). Euroamericans did not settle in Brown County before about 1856 , but the property line remained the same until 1941, when the parcels were combined into Camp Bowie. The wall's age and owners are unknown, but it could date any time between 1856 and 1941 .

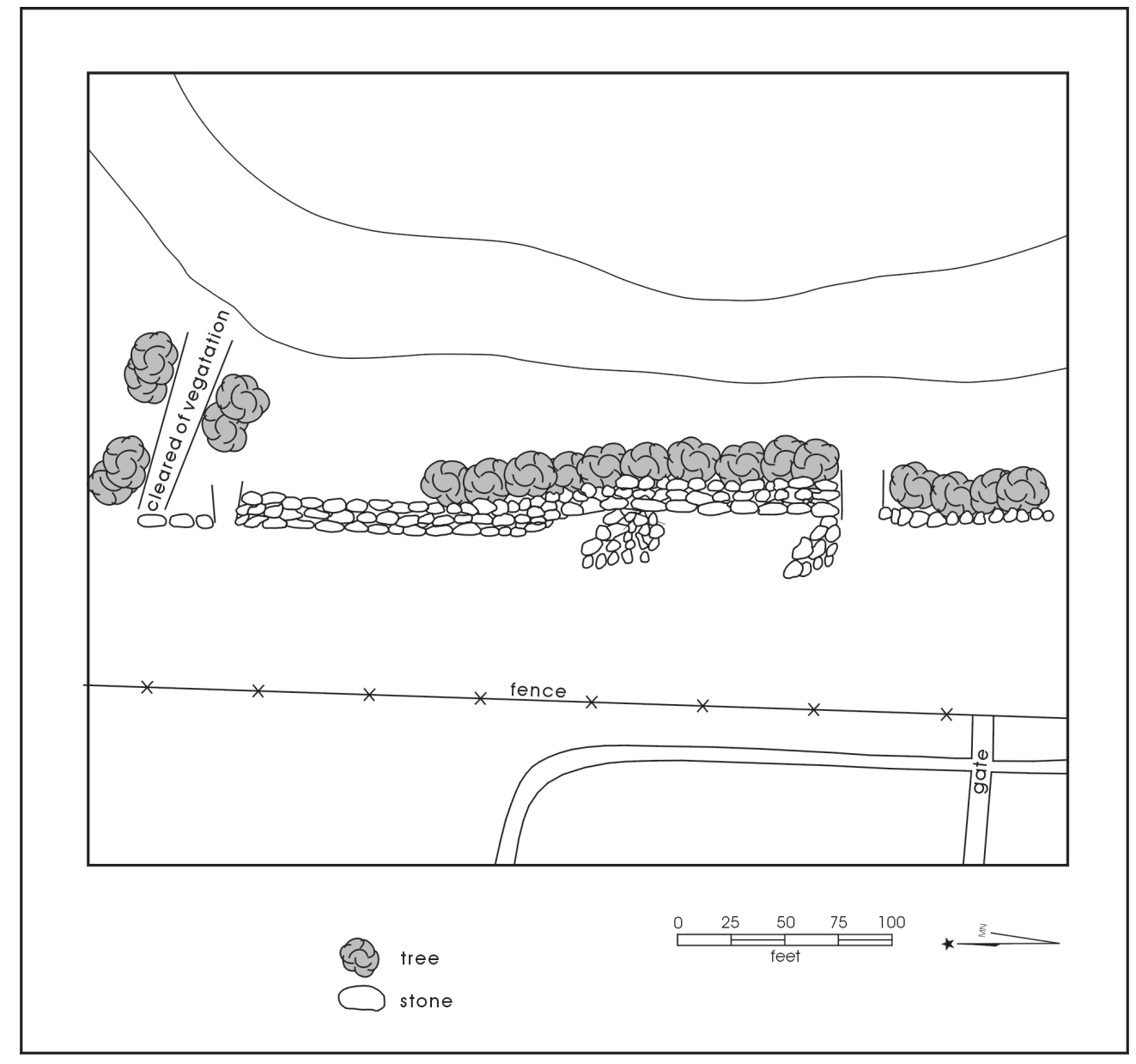

Figure A-1. Site map of 41 BR266. 
a north-south axis, it is constructed of dry stacked limestone and sandstone, ranging from a single course high (approximately $13 \mathrm{~cm}$ ) to three or four courses high (approximately $60 \mathrm{~cm}$ ). Areas of the wall have layered stone one to two meters wide.

\section{BR270}

This is a historic site consisting of the remains of five check dams that may be Works Progress Adminstration (WPA)era structures, dating to the 1930s (Figures A-2 and A-3). These structures are constructed of roughly cut limestone with concrete caps and facings, and are spaced out over an area measuring $110 \mathrm{~m}$ north-south by $35 \mathrm{~m}$ east-west. They were damaged or displaced when the drainage was later channelized for flood control.

\section{BR290}

41BR290 is a $90 \times 40-m$ historic farmstead. The site contains a windmill and masonry/concrete water tank. Inscribed on the tank is the date " $08 / 19 / 38$." Two modern metal sheds, a modern metal storage bin, a modern plywood structure, and fencing associated with swine raising are present. These modern materials appear to date to the 1980s. The site is located at $454 \mathrm{~m}$ amsl on a flat, wide ridgeline. An unnamed,

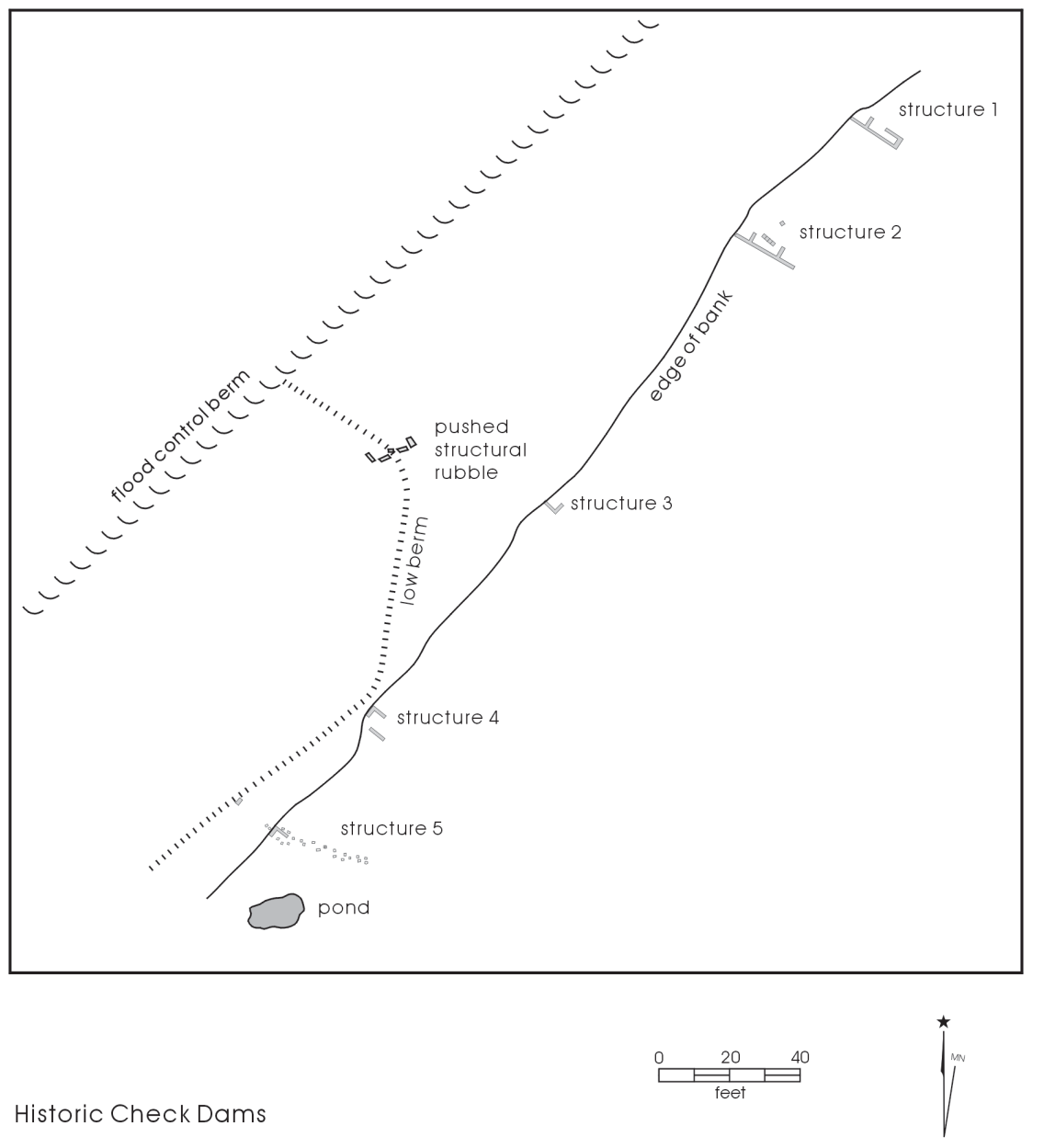

Figure A-2. Site map of 41 BR270 - overview of the site. 


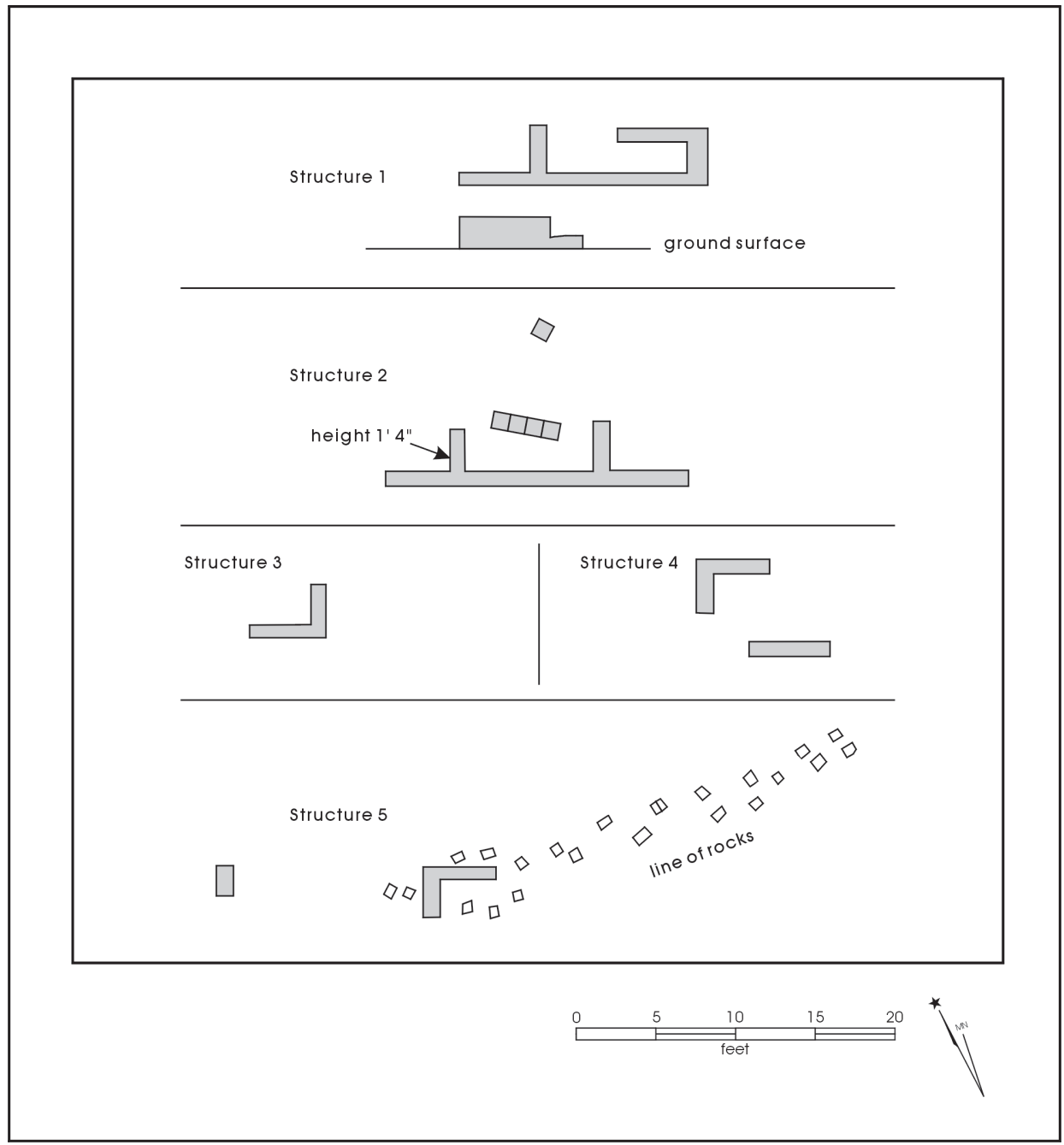

Figure A-3. Detail of the structures on $41 B R 270$.

intermittent drainage is located roughly $280 \mathrm{~m}$ to the north of the site. The surface of the site is a silt loam, and gravels are common. Vegetation observed at the time of the survey included live oak, mesquite, prickly pear, and grass. The area's ground surface visibility was 80 to 100 percent.

This site appears to represent the remains of a farmstead, possibly associated with ranching. In order to evaluate 41BR290, further documentation to establish association with specific persons or events will be required.

\section{BR299}

This site is a large historic military concrete bunker used for training purposes during World War II (Figure A-4). It is on a flat area southeast of a small ridgeline, with an unnamed tributary to Devil's River located $200 \mathrm{~m}$ to the northeast. The interior of the bunker is approximately 3.6 $\mathrm{m}$ wide by $7.3 \mathrm{~m}$ long, and is buried within an earthen berm measuring $19.5 \mathrm{~m}$ wide by $30 \mathrm{~m}$ long. The bunker is constructed of concrete that was poured into a frame made with 8-in. boards; their impressions can be seen on the bunker's ceiling. Graffiti dating from the 1940s, was also 


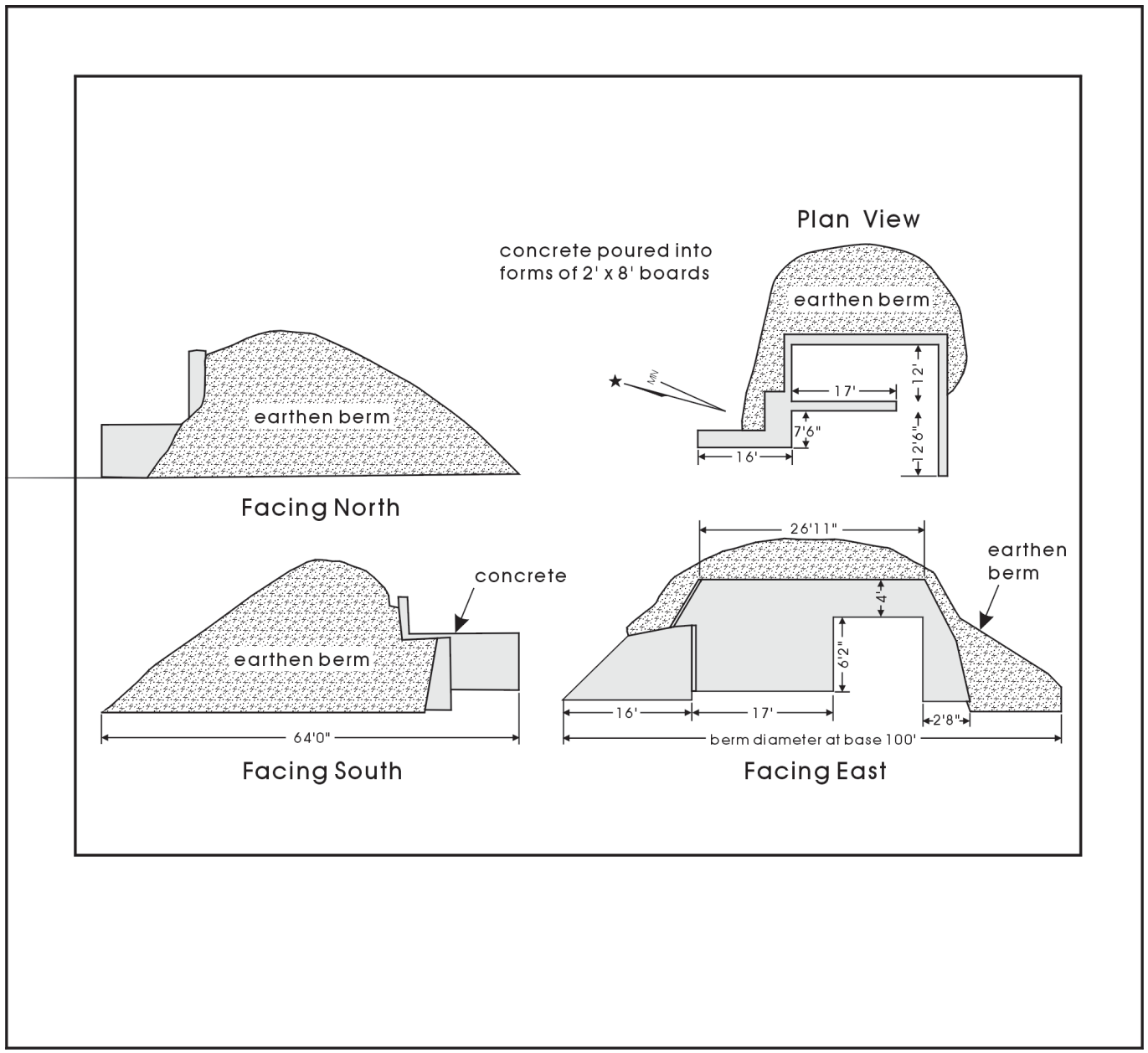

Figure A-4. Site map of 41BR299.

observed on the inside of the bunker. The berm is topped with rock rubble, and small oak trees, prickly pear, and grasses are growing on and around it. An earthen mound has also been built up along the east side of the bunker mound. One piece of clear glass was collected.

\section{BR438}

41BR438 (Figure A-5) is a historic site consisting of a stone wall, cistern, possible house foundation, and an associated scatter of artifacts. The wall is made of dry laid stone, approximately $60 \mathrm{~cm}$ wide and one meter high, and encloses a rectangular compound measuring roughly $21 \times 29 \mathrm{~m}$. The area within the wall appears to have been filled and leveled, as the wall measures only $15 \mathrm{~cm}$ above the ground surface on the inside, compared to $60 \mathrm{~cm}$ on the outside.

Within the compound is a rectangular house foundation measuring approximately $5.5 \times 8.2 \mathrm{~m}$, paved with shaped, limestone slabs. In one corner of the compound is a large, subterranean bell-shaped cistern measuring approximately 3.7 to $4.3 \mathrm{~m}$ deep, with the wall opening projecting $60 \mathrm{~cm}$ above the ground surface. The walls are approximately 30 $\mathrm{cm}$ thick and appear to be constructed of mortar-laid limestone slabs with concrete lining. Additionally, there is 


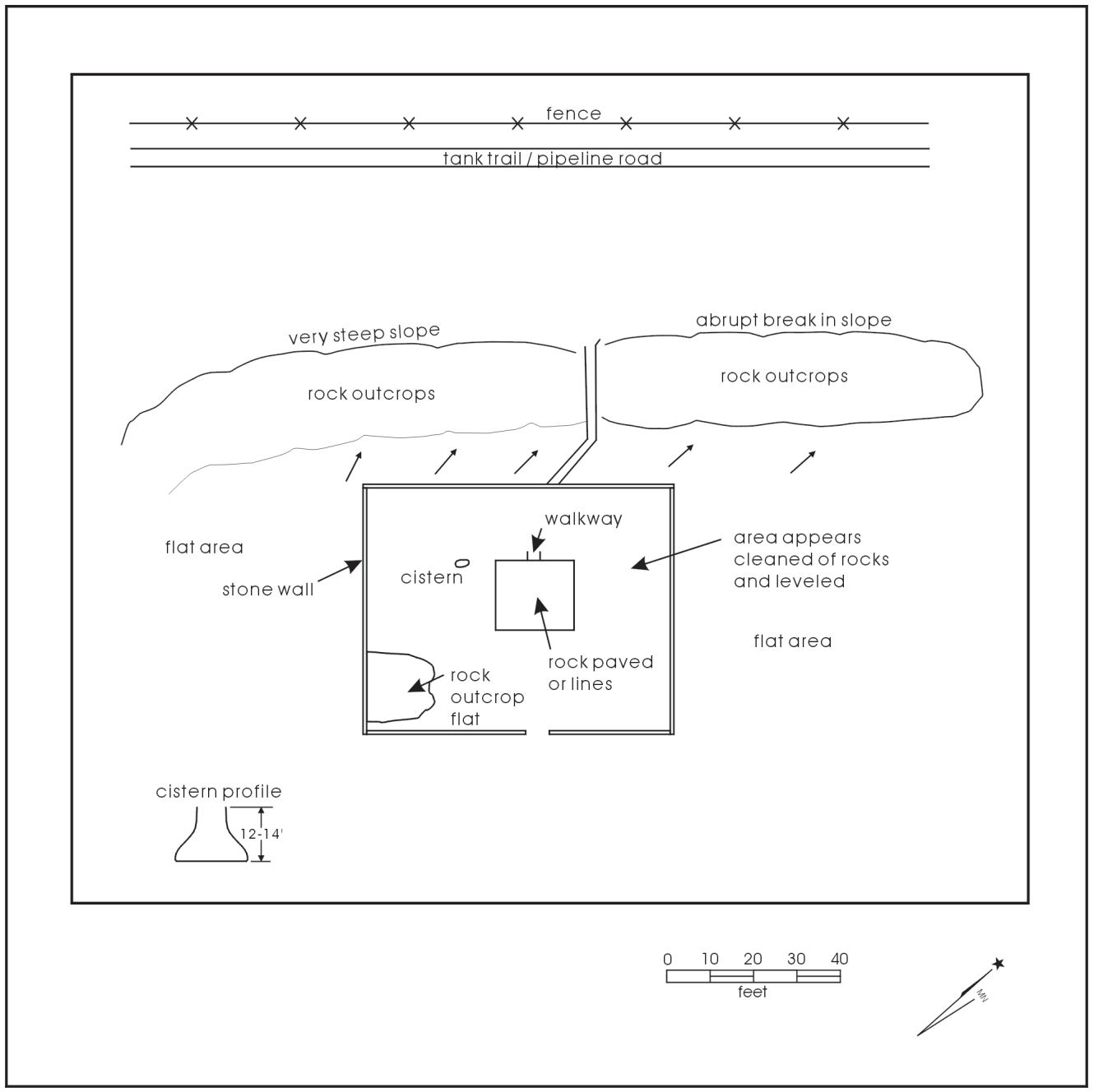

Figure A-5. Site map of $41 B R 438$.

a drainage channel excavated into the bedrock, extending northwest from the west stone wall of the compound, down the slope into the floodplain.

With surface visibility at 80 percent amidst the oak, mesquite, prickly pear, agarita, and bunch grasses, artifacts were easily seen and consisted of ceramic, glass, and metal items, indicating that the site may date to the late-nineteenth and/or early-twentieth century. One fragment of white granite ironstone and one fragment of stoneware were collected. Other artifacts observed included fragments of crockery, glass fragments (five clear, five solarized, and one brown), six pieces of rusty metal, a metal barrel band, a lard can, and a horseshoe. 


\section{BR477}

41BR477 (Figure A-6) is a series of six check dams in a gently sloping swale within a floodplain. The vegetation consists of mesquite, prickly pear, and grasses. The dams were constructed by the CCC or WPA in the late 1930s or early 1940s. Some of the dams are intact, while others have been badly damaged through time. All appear to be constructed of cut sandstone blocks and Portland cement. Based on the dimensions of one relatively complete dam, they seem to be approximately $18 \mathrm{~m}$ long by $3 \mathrm{~m}$ wide. Overall site dimensions (the extent of the series of dams) is $183 \mathrm{~m}(\mathrm{~N}-\mathrm{S})$ by $140 \mathrm{~m}(\mathrm{E}-\mathrm{W})$. The site's center is at an elevation of $439 \mathrm{~m}$ amsl.

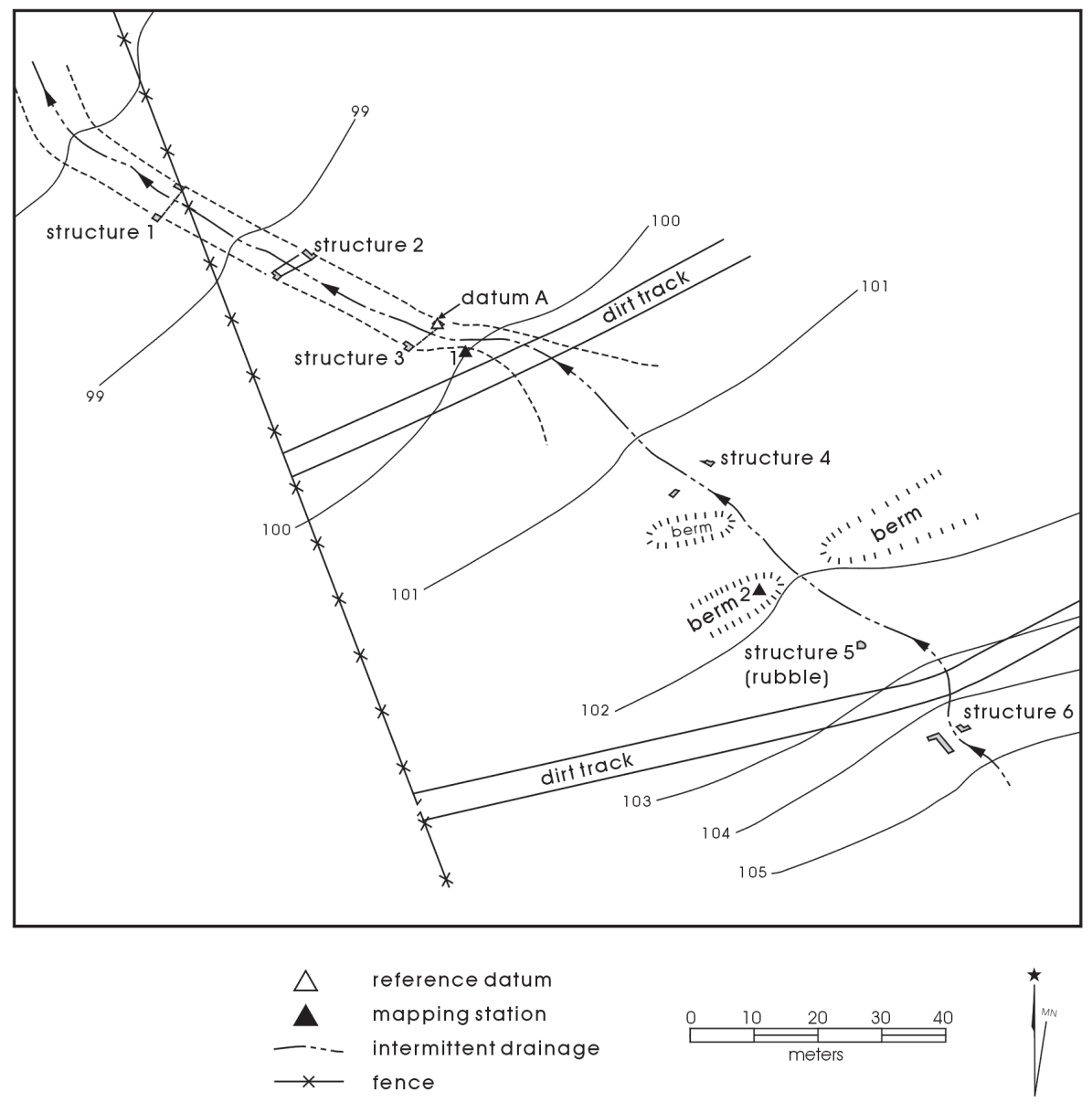

Figure A-6. Site map of $41 B R 477$. 


\section{References Cited}

Collins, M. B.

1995 Forty Years of Archeology in Central Texas. Bulletin of the Texas Archeological Society 66:361-400.

Johnson, L., and G. T. Goode

1994 A New Try at Dating and Characterizing Holocene Climates, as Well as Archeological Periods, on the Eastern Edwards Plateau. Bulletin of the Texas Archeological Society 65:1-51.

Turner, E. S., and T. R. Hester

1993 A Field Guide to Stone Artifacts of Texas Indians. Gulf Publishing Company, Houston. 